\title{
Acridizinium salts. Preparation from 1-(benzylic)-2-formyl and 1-(benzylic)-2-acetyl pyridinium bromides and ring-openings reactions with nucleophilic reagents
}

\author{
A. Paul Krapcho*, Sergio A. Cadamuro, and Lauren Macnee \\ Department of Chemistry, University of Vermont, Burlington, VT 05405 USA \\ E-mail: A.Paul.Krapcho@uvm.edu
}

Dedicated to Professor Berhanu Abegaz on his $60^{\text {th }}$ Birthday

\begin{abstract}
Treatment of pyridine-2-carboxaldehyde or 2-acetyl pyridine with several benzylic bromides led to the corresponding 1-(benzylic)-2-formyl pyridinium bromides or 1-(benzylic)-2-acetyl pyridinium bromides, respectively. The use of $\mathrm{MeOH}$ as a solvent in the quaternizations of pyridine-2-carboxaldehyde with benzylic bromides ( or in one case benzyl chloride) led to the corresponding pyridinium hemiacetals. These salts were effectively cyclodehydrated to afford the corresponding acridizinium salts. The ring opening reactions of several of the acridizinium salts with hydroxide, oximes, primary amines and a hydrazine have been investigated.
\end{abstract}

Keywords: Pyridinium salts, acridizinium salts, synthesis, ring opening reactions

\section{Introduction}

A recent review ${ }^{1}$ summarizes the status of the synthesis of benzo[b]quinolinium salts (acridizinium salts, Chart 1) and several previous reviews discuss the synthesis and reactions of these salts. $^{2,3,4}$ It was reported in $1955^{5}$ that treatment of pyridine 2-carboxaldehyde with benzyl bromide or 4-methyl benzyl bromide for 2-3 weeks at room temperature yielded dark red glassylike materials containing the corresponding pyridinium bromide salts. These crude glasses on refluxing with $48 \%$ aqueous $\mathrm{HBr}$ underwent cyclodehydrations to afford $60 \%$ and $39 \%$ (overall) yields of the corresponding acridizinium bromides (Chart 1). A similar glassy product was reported on treatment of $\alpha$-bromomethyl naphthalene with pyridine 2-carboxaldehyde which on refluxing with $48 \%$ aqueous $\mathrm{HBr}$ led to the substituted acridizinium bromide (52\% overall). ${ }^{6}$ Although it was initially reported that pyridine 2-carboxaldehyde with 3,4-dimethoxybenzyl bromide in DMF led to a crude glassy red product ${ }^{7}$, a more recent paper describes the isolation of 
an uncharacterized solid which on cyclization with $48 \%$ aqueous $\mathrm{HBr}$ yielded the substituted acridizinium salt. ${ }^{8}$<smiles></smiles><smiles>c1ccc2cc3ccccc3cc2c1</smiles>

benzo[b]quinolinium ion acridizinium ion

\section{Chart 1}

The use of methanol as a solvent for the quaternization of pyridine 2-carboxaldehyde with several methoxy substituted benzylic bromides led to crude uncharacterized products which could be cyclized to their respective acridizinium salts with $48 \%$ aqueous $\mathrm{HBr}^{9}$ A prior study has reported that treatment of 2-acetylpyridine with benzyl bromide (DMF, $10^{\circ} \mathrm{C}, 23$ days) led to a small amount of an oil which on cyclization with liquid HF led to 11-methylacridizinium (isolated as the perchlorate salt). ${ }^{10}$

The quaternizations of 2-(1,3-dioxolan-2-yl)pyridine ${ }^{11-16}$ were then reported to be much superior in reactions with benzylic bromides and the respective pyridinium salts could be converted into the acridizinium salts on acidic cyclodehydrations.

Our prior report documented that pyridine-2-carboxaldehyde with $\alpha, \alpha$-dibromo-o- or $\mathrm{p}$ xylenes led to the corresponding bis-pyridinium aldehydes which could be cyclized into the corresponding bis-acridizinium salts. ${ }^{17}$

The goal of the present research was to clearly establish the structures of the products formed from the quaternizations of pyridine 2-carboxaldehydes and 2-acetyl pyridine with benzylic halides and the evaluation of the use of methanol as a solvent in these reactions. These substituted pyridinium salts would be converted into the respective acridizinium salts on acidic cyclodehydrations This methodology would obviate the necessity for the use of pyridine acetals or oximes for the preparation of acridizinium salts. In addition, we wish to report on the ringopening reactions of several of the acridizinium salts with aqueous $\mathrm{NaOH}$ solutions, primary amines, oximes and hydrazines.

\section{Results and Discussion}

\section{Formation of the pyridinium salts}

Treatment of pyridine-2-carboxaldehyde (1) with benzyl bromide (2a), 4-methyl benzyl bromide (2b) or 2,5-dimethoxy benzyl bromide (2c) (1:1 molar ratios) in DMF as solvent at $40-45^{\circ} \mathrm{C}$ for 20-24 $\mathrm{h}$ led to the corresponding pyridinium salts $\mathbf{3 a}, \mathbf{3 b}$ and $\mathbf{3 c}$, respectively. These salts 
crystallized from the reaction mixture and were readily isolated by filtration in $50-57 \%$ yields. Although sensitive to moisture, they could be stored in the freezer for long periods without any perceptible decomposition. The isolation of the free aldehyde (or hydrate) is also dependent on the humidity during the filtration of the solids as under high humidity conditions the hydrates are the predominant product. In Vermont the winter months, when the humidity is low, were clearly the best times to run these reactions.<smiles>O=Cc1ccccn1</smiles>

1<smiles>[R]c1cc([R])c(CBr)cc1[R]</smiles>

2

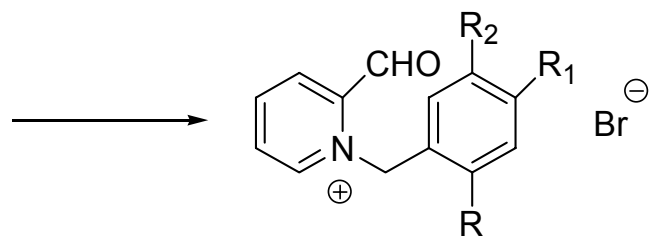

3

2 and 3: $a, R=R_{1}=R_{2}=H ; b, R=R_{2}=H, R_{1}=C H_{3} ; c, R=R_{2}=O C H_{3}, R_{1}=H$

In the ${ }^{1} \mathrm{H}$ NMR spectra (DMSO- $\mathrm{d}_{6}$ as solvent), the $\mathrm{CHO}$ proton of the aldehydes are found at $\delta 10.3$ and in the ${ }^{13} \mathrm{C} \mathrm{nmr}$ spectra the carbon appears at $\delta 183$. The facile hydrations of the aldehydes are easily detected by a comparison of the ${ }^{1} \mathrm{H}$ and ${ }^{13} \mathrm{C} \mathrm{nmr}$ spectra in the absence and presence of $\mathrm{D}_{2} \mathrm{O}$, respectively, which in the former indicates the disappearance of the signal at $\delta$ 10.3 and in the latter the disappearance of the signal at $\delta 183$.

The expected reactivity of the aldehyde group is demonstrated by treatment of a suspension of crystalline $\mathbf{3 a}$ in ethyl acetate followed by addition of $\mathrm{MeOH}$ to effect solution. On allowing this solution to stand in the freezer for several days, the resultant crystals were collected by filtration to afford the hemiacetal $4 \mathbf{a}$.

It was then observed that the quaternizations of $\mathbf{1}$ with $\mathbf{2 a}$ or $\mathbf{2 b}$ in refluxing $\mathrm{MeOH}$ as solvent directly led to the hemiacetals salts $\mathbf{4 a}(67 \%)$ and $\mathbf{4 b}(30 \%)$, respectively. Treatment of $\mathbf{1}$ with benzyl chloride in refluxing methanol led to hemiacetal chloride salt $4 \mathbf{c}(30 \%)$.<smiles>[R]c1ccc(C[n+]2ccccc2C(O)(O)OC)cc1</smiles>

4

$$
\begin{aligned}
& \text { a, } X=\mathrm{Br}, \mathrm{R}=\mathrm{H} \\
& \mathrm{b}, \mathrm{X}=\mathrm{Br}, \mathrm{R}=\mathrm{CH}_{3} \\
& \mathrm{c}, \mathrm{X}=\mathrm{Cl}, \mathrm{R}=\mathrm{H}
\end{aligned}
$$

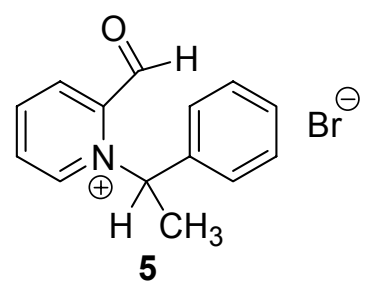

5<smiles></smiles><smiles>[BiH]</smiles>

Attempts to prepare 5 by treatment of pyridine 2-carboxaldehyde (1) with $\alpha$ bromoethylbenzene in DMF were unsuccessful. Styrene is rapidly formed by $\beta$-elimination from the $\alpha$-bromoethylbenzene. The preparation of 6 was accomplished by treatment of the 
corresponding acetal of 2 -acetyl pyridine with $\alpha$-bromoethylbenzene following a modified literature procedure. ${ }^{12}$

We next turned our attention to the reactions of 2-acetyl pyridine (7) with benzylic bromides. Treatment of 2-acetyl pyridine (7) with an equimolar amount of benzyl bromide (2a) at $60^{\circ} \mathrm{C}$ in DMF for $48 \mathrm{~h}$ led to 1-(benzyl)-2-acetyl pyridinium bromide (8a) in a poor yield (13\%). An attempt was made to perform this quaternization in 2-propanol as solvent. After $65 \mathrm{~h}$ at room temperature and $45^{\circ} \mathrm{C}$ for $48 \mathrm{~h}$, the only identifiable material $\left({ }^{1} \mathrm{H} \mathrm{NMR}\right)$ was the hydrobromide salt of 2-acetyl pyridine. Clearly the rate of reaction of benzyl bromide with 2propanol (formation of $\mathrm{HBr}$ ) is competitive with the anticipated quaternization process.

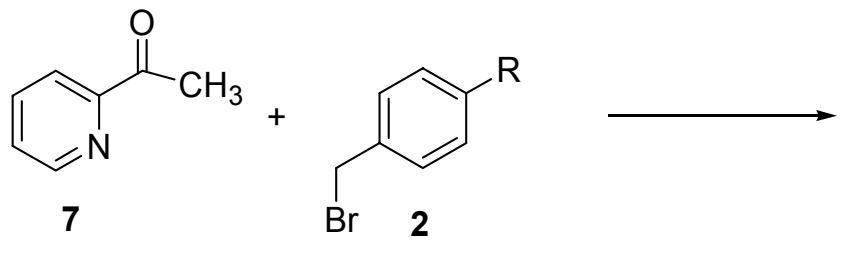
a) $\mathrm{R}=\mathrm{H}$
b) $\mathrm{R}=\mathrm{CH}_{3}$
a) $\mathrm{R}=\mathrm{H}$
b) $\mathrm{R}=\mathrm{CH}_{3}$

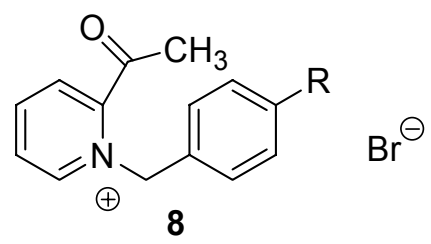

Treatment of 2-acetyl pyridine (7) with an equimolar quantity of 4-methyl benzyl bromide (2b, DMF, $45-50^{\circ} \mathrm{C}, 216 \mathrm{~h}$ ) led to 1-(4-methylbenzyl)-2-acetyl pyridinium bromide $\mathbf{8 b}(36 \%)$.

\section{Acridizinium salts}

The cyclodehydrations of the pyridinium salts $\mathbf{3 a - c}, \mathbf{6}$ and $\mathbf{8 a}, \mathbf{b}$ to the corresponding acridizinium salts 9 were accomplished by heating in $48 \%$ aqueous $\mathrm{HBr}$ and precipitation of the salts by the addition of THF. The yields and reactions conditions are tabulated in Table 1. Only 8a cyclized in an extremely poor yield (10\%) while $\mathbf{3 c}$ readily underwent cyclization. Hemiacetal $4 \mathbf{a}$ also readily cyclized to afford $\mathbf{9 a}$. The corresponding tetrafluoroborate salt $\mathbf{9 a}$ (where $\mathrm{Br}=\mathrm{BF}_{4}$ ) could be isolated on heating 3a in aqueous tetrafluoroboric acid. Cyclodehydration of $\mathbf{4 c}$ in concentrated $\mathrm{HCl}$ led to acridizinium chloride $\mathbf{9 a}($ where $\mathrm{Br}=\mathrm{Cl})$.

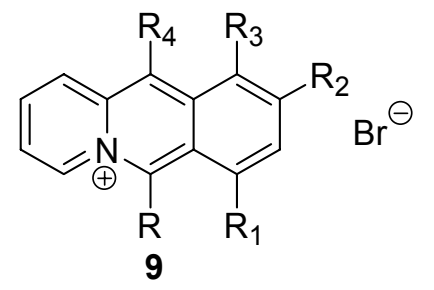

a) $R=R_{1}=R_{2}=R_{3}=R_{4}=H$

b) $\mathrm{R}=\mathrm{R}_{1}=\mathrm{R}_{3}=\mathrm{R}_{4}=\mathrm{H}, \mathrm{R}_{2}=\mathrm{CH}_{3}$

c) $R=R_{2}=R_{4}=H, R_{1}=R_{3}=O_{3}$

d) $\mathrm{R}_{1}=\mathrm{R}_{2}=\mathrm{R}_{3}=\mathrm{R}_{4}=\mathrm{H}, \mathrm{R}=\mathrm{CH}_{3}$

e) $R=R_{1}=R_{2}=R_{3}=H, R_{4}=C_{3}$

f) $R=R_{1}=R_{3}=H, R_{2}=R_{4}=C_{3}$

The ${ }^{1} \mathrm{H}$ NMR absorptions for the singlets (DMSO-d $\mathrm{d}_{6}$ ) at H-6 (except 6) and H-11 (except 9e and f) are also tabulated in Table 1. 
Table 1. Reaction conditions, yields and ${ }^{1} \mathrm{H}$ NMR data for the acridizinium salts 9a-f

\begin{tabular}{|c|c|c|c|c|c|}
\hline $\begin{array}{c}\text { Pyridinium } \\
\text { Salt }\end{array}$ & $\begin{array}{c}\text { Acridizinium } \\
\text { Salt }\end{array}$ & Temp, h & \% Yield & H-6 & H-11 \\
\hline 3a & 9a & $90^{\circ} \mathrm{C}, 2 \mathrm{~h}$ & 87 & 10.51 & 9.31 \\
\hline $\mathbf{3 b}$ & 9b & $90^{\circ} \mathrm{C}, 2 \mathrm{~h}$ & 90 & 10.39 & 9.09 \\
\hline $\mathbf{3 c}$ & 9c & $50^{\circ} \mathrm{C}, 0.5 \mathrm{~h}$ & quant & 10.41 & 9.26 \\
\hline $\mathbf{6}$ & 9d & $70-90^{\circ} \mathrm{C}, 4 \mathrm{~h}$ & 70 & - & 9.23 \\
\hline $\mathbf{8 a}$ & 9e & $95-100^{\circ} \mathrm{C}, 3 \mathrm{~h}$ & 13 & 10.40 & - \\
\hline $\mathbf{8 b}$ & 9f & $120-130^{\circ} \mathrm{C}, 1.5 \mathrm{~h}$ & 56 & 10.35 & - \\
\hline
\end{tabular}

\section{Nucleophilic ring openings of the acridizinium salts}

It has been previously reported that treatment of acridizinium bromide (9a ) in water with a $10 \%$ aqueous $\mathrm{NaOH}$ solution led to an orange precipitate which was tentatively identified as a mixture of the pseudo base $\mathbf{1 0}$ and ring-opened aldehyde 11a. ${ }^{18,19}$<smiles>O=CC1(O)c2ccccc2C=C2C=CC=CN21</smiles><smiles>[R]c1ccc(C([R])[Y])c(Cc2ccccn2)c1</smiles>

a, $\mathrm{R}=\mathrm{R}_{1}=\mathrm{H}, \mathrm{X}=\mathrm{O}$

b, $\mathrm{R}=\mathrm{H}, \mathrm{R}_{1}=\mathrm{CH}_{3}, \mathrm{X}=\mathrm{O}$

c, $\mathrm{R}=\mathrm{CH}_{3}, \mathrm{R}_{1}=\mathrm{H}, \mathrm{X}=\mathrm{O}$

d, $R=R_{1}=H, X=N O H$

e, $\mathrm{R}=\mathrm{H}, \mathrm{R}_{1}=\mathrm{CH}_{3}, \mathrm{X}=\mathrm{NOH}$

$\mathrm{f}, \mathrm{R}=\mathrm{R}_{1}=\mathrm{H}, \mathrm{X}=\mathrm{NOCH}_{2} \mathrm{Ph}$

$\mathrm{g}, \mathrm{R}=\mathrm{CH}_{3}, \mathrm{R}_{1}=\mathrm{H}, \mathrm{X}=\mathrm{NOH}$

h, $\mathrm{R}=\mathrm{H}, \mathrm{R}_{1}=\mathrm{CH}_{3}, \mathrm{X}=\mathrm{N}\left(\mathrm{CH}_{2}\right)_{2} \mathrm{CH}_{3}$

$\mathrm{i}, \mathrm{R}=\mathrm{R}_{1}=\mathrm{H}, \mathrm{X}=\mathrm{N}\left(\mathrm{CH}_{2}\right)_{2} \mathrm{~N}\left(\mathrm{CH}_{3}\right)_{2}$

$\mathrm{j}, \mathrm{R}=\mathrm{R}_{1}=\mathrm{H}, \mathrm{X}=\mathrm{NN}\left(\mathrm{CH}_{3}\right)_{2}$

We initially evaluated the stability of acridizinium bromide (9a) in aqueous solutions of varying $\mathrm{pH}$. The acridizinium bromide was dissolved in 4 aqueous solutions at different $\mathrm{pH}$ values: $8\left(\mathrm{NaHCO}_{3}\right), 9-10\left(\mathrm{NaHCO}_{3} / \mathrm{Na}_{2} \mathrm{CO}_{3}\right), 11\left(\mathrm{NaHCO}_{3} / \mathrm{Na}_{2} \mathrm{CO}_{3}\right)$ and $12\left(\mathrm{Na}_{2} \mathrm{CO}_{3}\right)$. The salt was stable in $\mathrm{NaHCO}_{3}$ solutions at $\mathrm{pH}$ 8, the solution at $\mathrm{pH} 9-10$ formed a orange precipitate after a few minutes while the solutions at $\mathrm{pH} 11$ and 12 formed orange precipitates immediately on addition of the salt.

Attempts to establish the structure of the orange solid via ${ }^{1} \mathrm{H}$ NMR spectroscopy, as prepared via the procedure described by Bradsher, ${ }^{18}$ were only partially successful. It was impossible to obtain a pure sample of the pseudo base previously formulated as $\mathbf{1 0}$. The stability of the original solid isolated from the reactions was dependent on the solvent used in the ${ }^{1} \mathrm{H}$ NMR analysis such as $\mathrm{CDCl}_{3}$ or $\mathrm{C}_{6} \mathrm{D}_{6}$. If the initial crude solid obtained from treatment of acridiziniium bromide (9a) was collected and dried for a short period and the ${ }^{1} \mathrm{H}$ NMR recorded in $\mathrm{CDCl}_{3}$, a complex spectra indicated the presence of the ring-opened aldehyde [absorptions at $\delta$ $10.29(\mathrm{CHO})$ and $\left.4.60\left(\mathrm{CH}_{2}\right)\right]$ along with numerous additional absorptions which were difficult to assign. If the same procedure was repeated and the ${ }^{1} \mathrm{H}$ NMR recorded in $\mathrm{C}_{6} \mathrm{D}_{6}$ [ absorptions at $\delta 10.2(\mathrm{CHO})$ and $\left.4.4\left(\mathrm{CH}_{2}\right)\right]$ the proportion of ring-opened product was reduced 
(approximately10\%) but the integrals for the remaining protons amounted to approximately 2527 protons, indicative of the presence of several species. If the solutions of the $\mathrm{CDCl}_{3}$ and $\mathrm{C}_{6} \mathrm{D}_{6}$ were allowed to stand for 20 hours, the predominant product was the ring-opened aldehyde 11a. On allowing the crude orange product to stand in the air for 2 days, the ${ }^{1} \mathrm{H}$ NMR spectrum $\left(\mathrm{CDCl}_{3}\right.$ or $\mathrm{C}_{6} \mathrm{D}_{6}$ as solvents) did not show much change in composition.

Treatment of an aqueous solution of acridizinim bromide (9a) with $0.1 \%(\mathrm{pH}=12.5), 2 \%$ $(\mathrm{pH}=14)$ or $10 \%(\mathrm{pH}=14)$ aqueous $\mathrm{NaOH}$ led to an orange solid which was then extracted into $\mathrm{CDCl}_{3}$ in each case. The ${ }^{1} \mathrm{H}$ NMR spectra in each case indicated the presence of the ringopened aldehyde 11a with only relative minor absorptions for other species. These solutions on removal of the $\mathrm{CDCl}_{3}$ led to black residues which on dissolving in $\mathrm{CDCl}_{3}$ and ${ }^{1} \mathrm{H} \mathrm{NMR}$ still indicated the presence of the aldehyde 11a. Treatment of the 9-methyl acridizinium bromide (9b) with a $0.1 \%$ aqueous solution of $\mathrm{NaOH}$ followed by extraction into $\mathrm{CDCl}_{3}$ and ${ }^{1} \mathrm{H} \mathrm{NMR}$ analysis indicated the presence of the ring-opened aldehyde 11b. Similarly the 6-methyl acridizinium bromide (9d) with $2 \%$ aqueous $\mathrm{NaOH}$ followed by $\mathrm{CDCl}_{3}$ extraction and $1 \mathrm{H} \mathrm{NMR}$ analysis indicated the major product as the ring-open ketone 11c.

The cyclization of the crude orange product, obtained from 9a on treatment with aqueous $\mathrm{NaOH}$, using $48 \%$ aqueous $\mathrm{HBr}$ readily led to an excellent yield of 9a.

Treatment of acridizinium bromide (9a) or 9-methyl acridizinium bromide (9b) with hydroxylamine ( prepared by addition of aqueous $\mathrm{NaHCO}_{3}$ to aqueous hydroxylamine hydrochloride) yielded the oximes 11d (68\%) and 11e (90\%), respectively. The reaction of Obenzylhydroxylamine with acridizinium bromide (9a) gave the substituted oxime 11f (62\%). Similarly the addition of hydroxylamine to 6-methyl acridizinium bromide (9d) led to the oxime $11 \mathrm{~g}(68 \%)$. In this case the proton NMR indicated the presence of $\mathrm{E}$ and $\mathrm{Z}$ isomers as shown by the peaks at $\delta 10.97$ and 10.40 (ratio 9:1), 4.18 and 4.00 (ratio 9:1) and 1.99 and 1.91 (9:1). In the ${ }^{1} \mathrm{H}$ NMR spectrum in $\mathrm{DMSO}_{-} \mathrm{d}_{6}+\mathrm{D}_{2} \mathrm{O}$, the disappearance of the $\delta 10.97$ and 10.40 absorptions occurred.

Since the $\mathrm{pH}$ of the aqueous hydroxylamine solution remains at 8 , this suggests that the oximes arise from an initial attack of the nitrogen electron pair at C-6 of the corresponding acridizinium bromide to yield intermediates which rapidly undergo ring-openings.

The cyclization of oxime 11e on heating in $48 \%$ aqueous $\mathrm{HBr}$ led to 9-methyl acridizinium bromide $(\mathbf{9 b})$.

In order to more fully evaluate the ring-opening reactions, the acridizinium bromides were treated with several primary amines and N,N-dimethylhydrazine. Treatment of 9-methyl acridizinium bromide (9b) with 1-aminopropane led to $\mathbf{1 1 h}(78 \%)$ while acridizinium bromide (9a) on addition of $N, N$-dimethylethylenediamine led to the imine 11i (quantitative). Both imines were readily identified by ${ }^{1} \mathrm{~N}$ NMR and ${ }^{13} \mathrm{C}$ NMR analysis. These imines were unstable on exposure to air for short periods. It might be noted that imine $\mathbf{1 1 h}$ on heating in $48 \%$ aqueous $\mathrm{HBr}$ led to 9-methyl acridizinium bromide (9b) which was contaminated with the hydrobromide salt of 1-aminopropane ( ${ }^{1} \mathrm{H}$ NMR analysis). On the other hand treatment of 9a with the secondary amine pyrrolidine led to an immediate red coloration but which on workup, no 
identifiable products could be isolated or characterized by ${ }^{1} \mathrm{H}$ NMR. A similar result has previously been reported on treatment of $9 \mathbf{a}$ with piperidine. ${ }^{20}$

Acridizinium bromide (9a) on treatment with N,N-dimethylhydrazine afforded hydrazone 11j (78\%).

In conlusion, we have shown that the use of pyridine 2-carboxaldehyde and 2-acetyl pyridine in reactions with benzylic bromides leads to the direct synthesis of pyridinium salts. The use of methanol as solvent in the reactions of pyridine 2-carboxaldehyde with benzylic halides led to the corresponding pyridinium hemiacetals. These salts undergo cyclizations in $48 \%$ aqueous $\mathrm{HBr}$ (also $\mathrm{HBF}_{4}$ and $\mathrm{HCl}$ ) ) to afford the corresponding acridizinium salts. The acridizinium salts undergo facile ring opening reactions with aqueous $\mathrm{NaOH}$, oximes, primary amines and 1,1,-dimethylhydrazine to afford the corresponding ring-opened products. The structure of the intermediate obtained from treatment of acridizinium bromide with aqueous $\mathrm{NaOH}$, could not be firmly established because of facile ring-openings. However, the ring opened products and acidic cyclizations of the crude orange intermediate to the acridizinium salt are quite consistent with the proposed structure $\mathbf{1 0}$.

\section{Experimental Section}

General Procedures: The pyridine 2-carboxaldehyde (1), 2-acetyl pyridine and benzylic bromides 2a and $\mathbf{2 b}$ were purchased from Acros. Melting points were taken on a Fisher-Johns or a Mel Temp II apparatus and are uncorrected. The ${ }^{1} \mathrm{H}$ NMR and ${ }^{13} \mathrm{C}$ NMR data were acquired on a Bruker ARX-500 pulsed spectrometer with TMS or the solvent as an internal standard.

\section{Pyridinium salts}

1-Benzyl-2-formyl pyridinium bromide (3a). Pyridine-2-carboxaldehyde (1) (1.22 g, 11.1 mmol) and benzyl bromide (2a) $(1.73 \mathrm{~g}, 10.0 \mathrm{mmol})$ were dissolved in DMF $(1 \mathrm{~mL})$ and the solution was heated in an oil bath held at $45^{\circ} \mathrm{C}$ for $24 \mathrm{~h}$ during which time a crystalline, yellow solid separated. After cooling, the crystals were collected by filtration and washed thoroughly with ether to afford 3a as a orange crystalline solid $(1.70 \mathrm{~g}, 61 \%)$ which was hygroscopic, $\mathrm{mp}$ 179-184 (dec., black liquid). Attempts to recrystallize this product were unsuccessful but the product could be stored in the freezer for long periods, ${ }^{1} \mathrm{H}$ NMR $\left(\right.$ DMSO- $\left._{6}\right) \delta 10.39(\mathrm{~s}, 1 \mathrm{H})$, $9.30(\mathrm{~d}, \mathrm{~J}=5.9 \mathrm{~Hz}, 1 \mathrm{H}), 8.91(\mathrm{t}, \mathrm{J}=7.7 \mathrm{~Hz}, 1 \mathrm{H}), 8.63(\mathrm{t}, \mathrm{J}=7.8 \mathrm{~Hz}, 1 \mathrm{H}), 8.47-8.41(\mathrm{~m}, 1 \mathrm{H})$, 7.48-7.36 (m, 5H), $6.37(\mathrm{~s}, 2 \mathrm{H}) .{ }^{1} \mathrm{H}$ NMR $\left(\mathrm{DMSO}^{-\mathrm{d}_{6}}+\mathrm{D}_{2} \mathrm{O}\right) \delta 9.01(\mathrm{~d}, \mathrm{~J}=5.9 \mathrm{~Hz}, 1 \mathrm{H}), 8.69(\mathrm{t}, \mathrm{J}$ $=7.8 \mathrm{~Hz}, 1 \mathrm{H}), 8.37(\mathrm{~d}, \mathrm{~J}=8.0 \mathrm{~Hz}, 1 \mathrm{H}), 8.11,(\mathrm{t}, \mathrm{J}=7.0 \mathrm{~Hz}, 1 \mathrm{H}), 7.43-7.37(\mathrm{~m}, 3 \mathrm{H}), 7.21-7.29$ $(\mathrm{m}, 2 \mathrm{H}), 6.20(\mathrm{~s}, 1 \mathrm{H}), 6.05(\mathrm{~s}, 2 \mathrm{H}) .{ }^{13} \mathrm{C}$ NMR $\left(\mathrm{DMSO}_{6}\right) \delta 183.4,147.3,147.2,133.91,131.2$, 130.0, 129.1, 129.0, 127.99, 127.8, 59.8. ${ }^{13} \mathrm{C}$ NMR (DMSO-d $\left.\mathrm{d}_{6}+\mathrm{D}_{2} \mathrm{O}\right) \delta 156.8,147.2,146.7$, 134.2, 123.5, 129.2, 128.0, 127.8, 126.2, 85.2, 53.8. Anal. Calcd. for $\mathrm{C}_{13} \mathrm{H}_{12} \mathrm{BrNO} 0.4 \mathrm{H}_{2} \mathrm{O}: \mathrm{C}$, 54.67, H, 4.48, N, 4.90. Found: C, 54.96, H, 4.33, N, 4.97.

1-(4-Methylbenzyl)-2-formyl pyridinium bromide (3b). Pyridine-2-carboxaldehyde (1) (2.4 g, $20.0 \mathrm{mmol}$ ) and 4-methylbenzyl bromide (2b) $(3.7 \mathrm{~g}, 20 \mathrm{mmol})$ were dissolved in DMF (3 $\mathrm{mL})$ 
and the solution was heated in an oil bath at $45-50^{\circ} \mathrm{C}$ for 44 hours during which time the product commenced to separate. After cooling, ether was added and the solid was collected by filtration and washed thoroughly with ether to afford $\mathbf{3 b}$ as pale yellow crystals (4.2 g, 72\%), mp 185$197^{\circ} \mathrm{C} .{ }^{1} \mathrm{H}-\mathrm{NMR}\left(\mathrm{DMSO}_{6}\right) \delta 10.39(\mathrm{~s}, 1 \mathrm{H}), 9.24(\mathrm{~d}, \mathrm{~J}=6.0 \mathrm{~Hz}, 1 \mathrm{H}), 8.88-8.84(\mathrm{~m}, 1 \mathrm{H}), 8.61-$ $8.58(\mathrm{~m}, 1 \mathrm{H}), 8.43-8.40(\mathrm{~m}, 1 \mathrm{H}), 7.30(\mathrm{~d}, \mathrm{~J}=8.1 \mathrm{~Hz}, 2 \mathrm{H}), 7.24(\mathrm{~d}, \mathrm{~J}=8.1 \mathrm{~Hz}, 2 \mathrm{H}), 6.30(\mathrm{~s}, 2 \mathrm{H})$, $2.31(\mathrm{~s}, 3 \mathrm{H}) .{ }^{1} \mathrm{H}$ NMR $\left(\mathrm{DMSO}_{-} \mathrm{d}_{6}+\mathrm{D}_{2} \mathrm{O}\right) \delta 8.31(\mathrm{~d}, \mathrm{~J}=5.9 \mathrm{~Hz}, 1 \mathrm{H}), 8.64(\mathrm{t}, \mathrm{J}=7.6 \mathrm{~Hz}, 1 \mathrm{H})$, $8.34(\mathrm{~d}, \mathrm{~J}=7.3 \mathrm{~Hz}, 1 \mathrm{H}), 8.07(\mathrm{t}, \mathrm{J}=6.8 \mathrm{~Hz}, 1 \mathrm{H}), 7.23-7.17(\mathrm{~m}, 4 \mathrm{H}), 6.19(\mathrm{~s}, 1 \mathrm{H}), 5.95(\mathrm{~s}, 2 \mathrm{H})$, $2.26(\mathrm{~s}, 3 \mathrm{H}) .{ }^{13} \mathrm{C}$ NMR $\left(\mathrm{DMSO}_{-} \mathrm{d}_{6}\right) \delta 183.4,147.2,147.0,144.2,138.7,131.2,130.9,129.8$, 129.7, 128.2, 59.6, 20.6. ${ }^{13} \mathrm{C}$ NMR $\left(\mathrm{DMSO}_{-} \mathrm{d}_{6}+\mathrm{D}_{2} \mathrm{O}\right) \delta 156.8,147.3,146.7,139.2,131.2,130.2$, 128.4, 128.0, 126.3, 85.4, 59.8, 21.1. Anal. Calcd. for $\mathrm{C}_{14} \mathrm{H}_{14} \mathrm{BrNO}$ : C, 57.55, H, 4.83, N, 4.79. Found: C, 57.32, H, 4.60, N, 4.59.

1-(2,5-Dimethoxybenzyl)-2-formylpyridinium bromide (3c). A mixture of pyridine-2carboxaldehyde (1) $(0.31 \mathrm{~g}, 2.5 \mathrm{mmol})$ and 2,5-dimethoxy benzyl bromide (2c) (0.65 g, 2.8 mmol) on DMF $(0.05 \mathrm{~mL})$ was placed in an oil bath at $40^{\circ} \mathrm{C}$. After 6 hours crystals commenced to separate and the mixture was held at this temperature for a total of 24 hours. The solid was collected by filtration and washed with ether to afford beautiful orange crystals of $3 \mathbf{c}(0.48 \mathrm{~g}$, $50 \%$ ) which on ${ }^{1} \mathrm{H}$ NMR analysis indicated a residual trace of DMF and a small amount of the hydrate. This material was crystallized from acetonitrile to afford yellow-orange crystals, $\mathrm{mp}$ $138-140^{\circ} \mathrm{C} .{ }^{1} \mathrm{H}$ NMR (DMSO-d $\left.{ }_{6}\right) \delta 10.39(\mathrm{~s}, 1 \mathrm{H}), 9.17-9.13(\mathrm{~m}, 1 \mathrm{H}), 8.81(\mathrm{t}, \mathrm{J}=7.8 \mathrm{~Hz}, 1 \mathrm{H})$, 8.53-8.48 (m, 1H), 8.36-8.29 (m, 1H), $7.15(\mathrm{~d}, \mathrm{~J}=1.7 \mathrm{~Hz}, 1 \mathrm{H}), 7.04-6.99(\mathrm{~m}, 2 \mathrm{H}), 6.23(\mathrm{~s}, 2 \mathrm{H})$, $3.80(\mathrm{~s}, 3 \mathrm{H}), 3.62(\mathrm{~s}, 3 \mathrm{H}) .{ }^{1} \mathrm{H}$ NMR $\left(\mathrm{DMSO}_{-} \mathrm{d}_{6}+\mathrm{H}_{2} \mathrm{O}\right) \delta 8.78(\mathrm{~d}, \mathrm{~J}=6.1 \mathrm{~Hz}, 1 \mathrm{H}), 8.61(\mathrm{t}, \mathrm{J}=7.8$ $\mathrm{Hz}, 1 \mathrm{H}), 8.33$ (d, J = 8.0 Hz, 1H), 7.03-6.97 (m, 2H), 6.84 (d, J = 2.6 Hz, 1H), $6.31(\mathrm{~s}, 1 \mathrm{H}), 5.86$ $(\mathrm{s}, 1 \mathrm{H}), 3.68(\mathrm{~s}, 3 \mathrm{H}), 3.66(\mathrm{~s}, 3 \mathrm{H}) .{ }^{13} \mathrm{C} \mathrm{NMR}\left(\mathrm{DMSO}_{-} \mathrm{d}_{6}\right) \delta 183.4,153.2 ; 151.3,147.1,146.9$, 145.0, 157.1, 153.7, 151.7, 147.1, 146.2, 127.6, 56.0, 55.6, 55.5. ${ }^{13} \mathrm{C} \mathrm{NMR}\left(\mathrm{DMSO}_{-} \mathrm{d}_{6}+\mathrm{H}_{2} \mathrm{O}\right) \delta$ 157.1, 153.7, 151.7, 147.1, 146.2, 127.6, 125.8, 122.5, 116.9, 115.9, 113.3, 85.2, 56.5, 56.3, 56.1. Anal. Calcd. for $\mathrm{C}_{15} \mathrm{H}_{16} \mathrm{BrNO}_{3}$ : C, 53.27, H, 4.77, N, 4.14. Found: C, 52.98, H, 4.62, N, 4.07.

\section{Procedure 1. 1-(Benzyl)-2-(1-hydroxy-1-methoxymethyl)pyridinium bromide (4a).}

The orange crystalline 1-(benzyl)-2-formyl pyridinium bromide (3a) (84 $\mathrm{mg}, 0.30 \mathrm{mmol}$ ) was suspended in ethyl acetate $(2 \mathrm{ml})$ and the mixture heated while $\mathrm{MeOH}(0.5 \mathrm{~mL})$ was added to effect solution. On standing in the freezer for 4 days, the beautiful yellow crystals were collected by filtration, washed with ethyl acetate and allowed to air dry to afford hemiacetal $4 \mathbf{a}$ (70 mg, 75\%), mp $127-128^{\circ} \mathrm{C}$. This could be stored in a desiccator for long periods at room temperature. ${ }^{1} \mathrm{H}$ NMR $\left(\mathrm{DMSO}_{-} \mathrm{d}_{6}\right) \delta 9.06(\mathrm{~d}, \mathrm{~J}=5.9 \mathrm{~Hz}, 1 \mathrm{H}), 8.73(\mathrm{t}, \mathrm{J}=7.6 \mathrm{~Hz}, 1 \mathrm{H}), 8.37(\mathrm{~d}, \mathrm{~J}$ $=8.0 \mathrm{~Hz}, 1 \mathrm{H}), 8.18(\mathrm{t}, \mathrm{J}=7.6 \mathrm{~Hz}, 1 \mathrm{H}), 8.11(\mathrm{br} \mathrm{s}, 1 \mathrm{H}), 7.33-7.46(\mathrm{~m}, 3 \mathrm{H}), 7.33(\mathrm{~d}, \mathrm{~J}=6.7 \mathrm{~Hz}$, 2H), $6.04(\mathrm{~m}, 3 \mathrm{H}), 3.39(\mathrm{~s}, 3 \mathrm{H}) .{ }^{1} \mathrm{H}$ NMR $\left(\mathrm{DMSO}_{-} \mathrm{d}_{6}+\mathrm{D}_{2} \mathrm{O}\right) \delta 9.00(\mathrm{~d}, \mathrm{~J}=6.1 \mathrm{~Hz}, 1 \mathrm{H}), 8.71(\mathrm{t}, \mathrm{J}$ $=7.7 \mathrm{~Hz}, 1 \mathrm{H}), 8.35(\mathrm{~d}, \mathrm{~J}=8.0 \mathrm{~Hz}, 1 \mathrm{H}), 8.16(\mathrm{t}, \mathrm{J}=6.8 \mathrm{~Hz}, 1 \mathrm{H}), 7.35-7.45(\mathrm{~m}, 3 \mathrm{H}), 7.30(\mathrm{~d}, \mathrm{~J}=$ $6.9 \mathrm{~Hz}, 2 \mathrm{H}), 6.00(\mathrm{~m}, 3 \mathrm{H}), 3.40(\mathrm{~s}, 3 \mathrm{H}) .{ }^{13} \mathrm{C} \mathrm{NMR}\left(\mathrm{DMSO}_{6}\right) \delta$ 154.1, 146.9, 146.8, 134.0, 129.0, 128.8, 127.9, 127.8, 126.3, 91.6, 56.6, 54.2. Anal. Calcd. for C, 54.21, H, 5.20; N, 4.52. Found: C, 53.92, H, 4.98, N, 4.45. 


\section{Procedure 2. From pyridine-2- carboxaldehyde and benzyl bromide in $\mathrm{MeOH}$ (4a).}

The pyridine-2 carboxaldehyde (1) (1.07 g, $10 \mathrm{mmol})$ and benzyl bromide (2a, $1.71 \mathrm{~g}, 10 \mathrm{mmol})$ were dissolved in methanol $(4 \mathrm{~mL})$ and the mixture was refluxed for $2.3 \mathrm{~h}$ and allowed to stand overnight. The methanol was removed by rotary evaporation to afford a viscous yellow oil. Tetrahydrofuran $(50 \mathrm{~mL})$ was added to yield a yellow solid which was collected by filtration, washed with THF $(30 \mathrm{~mL})$ and dried to afford $2.08 \mathrm{~g}(67 \%)$ of crude product. A $1 \mathrm{~g}$ portion of this material was treated with ethyl acetate $(10 \mathrm{ml})$ and $\mathrm{MeOH}(1-2 \mathrm{~mL})$ was added to give a white solid which was collected by filtration and dried (4a, $0.70 \mathrm{~g}, 70 \%$ recovery), mp 122-124 with an identical ${ }^{1} \mathrm{H}$ NMR as the compound prepared in Procedure 1. Attempts to further purify by heating in ethyl acetate followed by addition of methanol led to nice crystals which on ${ }^{1} \mathrm{H}$ NMR analysis indicated the presence of a small amount of pyridinium aldehyde 3a.

1-(4-Methylbenzyl)-2-(1-hydroxy-1-methoxymethyl)pyridinium bromide (4b). The pyridine2 carboxaldehyde (1) (1.07 g, $10 \mathrm{mmol})$ and 4-methyl benzyl bromide (2b, $1.71 \mathrm{~g}, 10 \mathrm{mmol})$ were dissolved in methanol $(4 \mathrm{~mL})$ and the mixture was refluxed for $3.75 \mathrm{~h}$. The mixture was placed on the roto-vap to remove the solvent and allowed to stand overnight. The oil was treated with ethyl acetate and methanol was added. Upon cooling in the freezer $\mathbf{4 b}(0.90 \mathrm{~g}, 30 \%)$ was obtained. Attempts at crystallization from ethyl acetate-methanol led to crystals which contained some pyridinium aldehyde $\mathbf{3 b}, \mathrm{mp} 102-104^{\circ} \mathrm{C} .{ }^{1} \mathrm{H}$ NMR $\left(\mathrm{DMSO}_{\mathrm{d}}\right) \delta 8.98(\mathrm{~d}, \mathrm{~J}=6.0 \mathrm{~Hz}, 1 \mathrm{H})$, $8.71(\mathrm{t}, \mathrm{J}=7.7 \mathrm{~Hz}, 1 \mathrm{H}), 8.35(\mathrm{~d}, \mathrm{~J}=7.5 \mathrm{~Hz}, 1 \mathrm{H}), 8.14(\mathrm{~m}, 2 \mathrm{H}), 7.23$ (br s, 4H), 6.02 (d, J = $5 \mathrm{~Hz}$, $1 \mathrm{H}), 5.94(\mathrm{~s}, 2 \mathrm{H}), 3.4(\mathrm{~s}, 3 \mathrm{H}), 2.31(\mathrm{~s}, 3 \mathrm{H}):{ }^{1} \mathrm{H}$ NMR (DMSO- $\left.\mathrm{d}_{6}+\mathrm{D}_{2} \mathrm{O}\right)$ the multiplet at 8.14 (2H) merged into a triplet $(\mathrm{J}=7.5 \mathrm{~Hz}, 1 \mathrm{H})$

1-(Benzyl)-2-(1-hydroxy-1-methoxymethyl)pyridinium chloride (4c). The pyridine-2carboxaldehyde (1) (1.07 g, $10 \mathrm{mmol})$ and benzyl chloride $(1.27 \mathrm{~g}, 10 \mathrm{mmol})$ were dissolved in methanol $(4 \mathrm{~mL})$ and the mixture refluxed for $5 \mathrm{~h}$. The cooled mixture was placed on the rotary evaporator to remove the methanol which led to a yellow oil. Tetrahydrofuran $(40 \mathrm{~mL})$ was added and the mixture was placed in the freezer overnight. The somewhat oily solid was collected by filtration $(0.80 \mathrm{~g}, 30 \%)$. The material was placed in ethyl acetate and methanol was added on which a white solid formed. The white solid was collected by filtration $(0.30 \mathrm{~g}, 30 \%)$ and washed with THF; mp $131-134^{\circ} \mathrm{C}$. The ${ }^{1} \mathrm{H}$ NMR showed trace amounts of the pyridinium aldehyde. Attempts at crystallization from ethyl acetate-methanol led to beautiful crystals which by ${ }^{1} \mathrm{H}$ NMR were shown to contain more pyridinium aldehyde than the original solid. ${ }^{1} \mathrm{H}$ NMR $\left(\mathrm{DMSO}_{\mathrm{d}}\right)_{6} \delta .06(\mathrm{~d}, \mathrm{~J}=6.0 \mathrm{~Hz}, 1 \mathrm{H}), 8.72(\mathrm{t}, \mathrm{J}=8.0 \mathrm{~Hz}, 1 \mathrm{H}), 8.53($ br s, $1 \mathrm{H}), 8.36(\mathrm{~d}, \mathrm{~J}=8.0$ $\mathrm{Hz}, 1 \mathrm{H}), 8.17(\mathrm{t}, \mathrm{J}=6.0 \mathrm{~Hz}, 1 \mathrm{H}), 7.43(\mathrm{~m}, 3 \mathrm{H}), 7.35(\mathrm{~m}, 2 \mathrm{H}), 6.03(\mathrm{~m}, 3 \mathrm{H}), 3.41(\mathrm{~s}, 3 \mathrm{H}) .{ }^{1} \mathrm{H}$ NMR (DMSO- $\left.\mathrm{d}_{6}+\mathrm{H}_{2} \mathrm{O}\right) \delta$ disappearance of 8.53 (br s, 1H) indicates OH peak.

1-(1-Phenylethyl)2-(1,3-dioxolan-2-yl)pyridinium bromide (6). A solution of 2-(1,3dioxolan-2-yl)pyridine $(1.0 \mathrm{~g}, 6.6 \mathrm{mmol})$ and (1-bromoethyl)-benzene $(1.3 \mathrm{~g}, 6.6 \mathrm{mmol})$ in tetramethylene sulfone $(0.5 \mathrm{~mL})$ was allowed to stir at room temperature for 26 days (crystals started to form after 11 days). The product was collected by filtration and washed with ethyl acetate to afford yellow crystals of 6 (1.92 g, 82\%). Recrystallization from ethyl acetatemethanol led to beautiful colorless rhombic crystals, mp $139-140^{\circ} \mathrm{C}$; lit mp ${ }^{14} 140-141^{\circ} \mathrm{C} .{ }^{1} \mathrm{H}$ 
NMR (DMSO-d $)_{6} \delta 8.98(\mathrm{~d}, \mathrm{~J}=6.2 \mathrm{~Hz}, 1 \mathrm{H}), 8.67(\mathrm{t}, \mathrm{J}=7.8 \mathrm{~Hz}, 1 \mathrm{H}), 8.32(\mathrm{~d}, \mathrm{~J}=8.0 \mathrm{~Hz}, 1 \mathrm{H})$, ), $8.12(\mathrm{t}, \mathrm{J}=6.4 \mathrm{~Hz}, 1 \mathrm{H}), 7.47(\mathrm{~m}, 5 \mathrm{H}), 6.75(\mathrm{~s}, 1 \mathrm{H}), 6.56(\mathrm{q}, \mathrm{J}=6.8 \mathrm{~Hz}, 1 \mathrm{H}), 4.20(\mathrm{~m}, 4 \mathrm{H}), 2.04$ $(\mathrm{d}, \mathrm{J}=6.8 \mathrm{~Hz}, 3 \mathrm{H}) .{ }^{13} \mathrm{C}$ NMR $\left(\mathrm{DMSO}_{-} \mathrm{d}_{6}\right) \delta 151.6,146.9,144.7,137.5,129.1,128.9,128.8$, $127.6,125.7,97.3,65.7,65.6,64.6,20.4$.

1-(Benzyl)-2-acetyl pyridinium bromide (8a). The 2-acetyl pyridine (7) (1.28 g, $10 \mathrm{mmol})$ and benzyl bromide (2a) $1.81 \mathrm{~g}, 10 \mathrm{mmol}$ ) were dissolved in DMF (0.5 mL). The solution was placed in an oil bath held at $60^{\circ} \mathrm{C}$ and the mixture was held at this temperature for $48 \mathrm{~h}$. After about $24 \mathrm{~h}$ a yellow crystalline solid separated. The dark yellow- brown mixture was then placed in the freezer overnight. The resultant solid was collected by filtration and washed with THF (20 $\mathrm{mL}$ ) to afford $0.08 \mathrm{~g}$ of product $8 \mathbf{a}$. The filtrate deposited more product which was collected by filtration $(0.32 \mathrm{~g}$, total $0.40 \mathrm{~g}, 13 \%), \mathrm{mp} 105-107^{\circ} \mathrm{C}$. This material readily crystallized in nice needles from ethyl acetate-acetonitrile, mp $109-110^{\circ} \mathrm{C} .{ }^{1} \mathrm{H}$ NMR $\left(\mathrm{DMSO}-\mathrm{d}_{6}\right) \delta 9.31(\mathrm{~d}, \mathrm{~J}=6.1$ $\mathrm{Hz}, 1 \mathrm{H}), 8.78(\mathrm{t}, \mathrm{J}=7.9 \mathrm{~Hz}, 1 \mathrm{H}), 8.66(\mathrm{~d}, \mathrm{~J}=7.8 \mathrm{~Hz}, 1 \mathrm{H}), 8.36(\mathrm{t}, \mathrm{J}=7.5 \mathrm{~Hz}, 1 \mathrm{H}), 7.41(\mathrm{~m}, 3 \mathrm{H})$, $7.26(\mathrm{~m}, 2 \mathrm{H}), 5.97(\mathrm{~s}, 2 \mathrm{H}), 2.53(\mathrm{~s}, 3 \mathrm{H}) .{ }^{13} \mathrm{C}$ NMR $\left(\mathrm{DMSO}_{-} \mathrm{d}_{6}\right) \delta 194.8,148.3,148.2,147.5$, 134.0 129.9, 129.8, 128.9, 128.5, 128.2, 61.3, 30.1. Anal. Calcd. for $\mathrm{C}_{14} \mathrm{H}_{14} \mathrm{BrNO}$ : C, 57.55, H, 4.82, N, 4.79. Found: C, 57.50, H, 4.58, N, 4.65.

2-Acetyl pyridine hydrobromide. The 2-acetyl pyridine (7) (1.21 g, $10 \mathrm{mmol}$ ) and benzyl bromide (2a) (1.71 g, $10 \mathrm{mmol})$ were dissolved in 2-propanol $(3 \mathrm{~mL})$. The solution was stirred at room temperature for 65 hours during which time a small amount of a white solid started to precipitate. The bath temperature was raised to $45^{\circ} \mathrm{C}$ for $48 \mathrm{~h}$ and the mixture cooled in the refrigerator overnight. The solid was collected by filtration to afford $0.40 \mathrm{~g}$ of a hygroscopic solid identified as the hydrobromide salt of 2-acetylpyridine. ${ }^{1} \mathrm{H}$ NMR (DMSO- $\left.\mathrm{d}_{6}\right) \delta 8.76(\mathrm{~d}, \mathrm{~J}=$ $3.0 \mathrm{~Hz}, 1 \mathrm{H}), 8.15(\mathrm{~m}, 1 \mathrm{H}), 8.08(\mathrm{~m}, 1 \mathrm{H}), 8.0$ (br s, 1H), $7.78(\mathrm{~m}, 1 \mathrm{H}), 2.65(\mathrm{~s}, 3 \mathrm{H})$.

(4-Methylbenzyl)-2-acetyl pyridinium bromide (8b). The 2-acetylpyridine (7) (2.41 g, 20 mmol) and 4-methyl benzyl bromide (2b, $3.90 \mathrm{~g}, 20 \mathrm{mmol})$ were dissolved in DMF (2 $\mathrm{mL})$. The solution was placed in an oil bath held at about $45^{\circ}-50^{\circ} \mathrm{C}$ for 216 hours. The mixture was cooled to room temperature and the solid was collected by filtration and washed repeatedly with THF to afford a white solid $(2.2 \mathrm{~g}, 36 \%), \mathrm{mp} 134-135^{\circ} \mathrm{C}$. The solid readily crystallized from ethyl acetate and methanol to afford beautiful needles of $\mathbf{8 b}, \mathrm{mp} 135-136^{\circ} \mathrm{C} .{ }^{1} \mathrm{H}$ NMR $\left(\mathrm{DMSO}_{\mathrm{d}}\right.$ ) $\delta 9.25(\mathrm{~d}, \mathrm{~J}=5.9 \mathrm{~Hz}, 1 \mathrm{H}), 8.85(\mathrm{t}, \mathrm{J}=7.7 \mathrm{~Hz}, 1 \mathrm{H}), 8.62(\mathrm{~d}, \mathrm{~J}=8.0 \mathrm{~Hz}, 1 \mathrm{H}), 8.32(\mathrm{t}, \mathrm{J}$ $=6.9 \mathrm{~Hz}, 1 \mathrm{H}), 7.23(\mathrm{~d}, \mathrm{~J}=8.0 \mathrm{~Hz}, 2 \mathrm{H}), 7.17(\mathrm{~d}, \mathrm{~J}=8.1 \mathrm{~Hz}, 2 \mathrm{H}), 5.89(\mathrm{~s}, 2 \mathrm{H}), 2.58(\mathrm{~s}, 3 \mathrm{H}), 2.31$ $(\mathrm{s}, 3 \mathrm{H}) .{ }^{13} \mathrm{C}$ NMR $\left(\mathrm{DMSO}_{6}\right) \delta 194.9,148.5,147.9,147.4,138.6,130.90,129.8,129.5,128.4$, 128.3, 61.2, 30.1, 20.6. Anal. Calcd. for $\mathrm{C}_{15} \mathrm{H}_{16} \mathrm{BrNO}$ : C, 58.84; H, 5.27; N, 4.57. Found: C, 58.78, H, 4.99, N, 4.46.

\section{Acridizinium salts}

Procedure 1 (from 3a). Acridizinium bromide (9a). The 1-benzyl-2-formyl pyridinium bromide (3a) (325 mg, $1.2 \mathrm{mmol}$ ) was dissolved in 48\% aqueous $\mathrm{HBr}(1 \mathrm{~mL})$ and the solution heated in an oil bath held at $90-92^{\circ} \mathrm{C}$ for 2 hours. The cooled mixture was quenched into THF $(50 \mathrm{~mL})$ to afford the product as a bright yellow precipitate. The solid was collected by filtration, washed thoroughly with THF and air dried to yield $0.26 \mathrm{~g}(87 \%)$ of acridizinium 
bromide (9a) as a lemon-yellow solid; mp 250-252 ${ }^{\circ} \mathrm{C}$, lit. $^{7}$ 244-244.5 ${ }^{\circ} \mathrm{C} . \quad{ }^{1} \mathrm{H}$ NMR (DMSO-d 6 ) $\delta 10.51$ (s, 1H, H-6), 9.31 (d, J = 6.9 Hz, H-4), 9.27 (s, 1H, H-11), 8.58 (d, J = 8.6 Hz, 1H), 8.49 $(\mathrm{d}, \mathrm{J}=8.6 \mathrm{~Hz}, 1 \mathrm{H}), 8.41(\mathrm{~d}, \mathrm{~J}=8.6 \mathrm{~Hz}, 1 \mathrm{H}), 8.13(\mathrm{t}, \mathrm{J}=7.0 \mathrm{~Hz}, 1 \mathrm{H}), 8.10(\mathrm{t}, \mathrm{J}=7.0 \mathrm{~Hz}, 1 \mathrm{H})$, $8.03(\mathrm{t}, \mathrm{J}=7.0 \mathrm{~Hz}, 1 \mathrm{H}), 7.96(\mathrm{t}, \mathrm{J}=7.0 \mathrm{~Hz}, 1 \mathrm{H}):{ }^{13} \mathrm{C} \mathrm{NMR}\left(\mathrm{DMSO}_{-} \mathrm{d}_{6}+\mathrm{H}_{2} \mathrm{O}\right) \delta 139.8,137.9$, 136.0, 135.5, 134.4, 131.9, 131.8, 128.5, 127.6, 127.5, 126.5, 125.4, 123.4 .

Procedure 2 (from 4). The hemiacetal pyridinium salt $4 \mathbf{a}(43 \mathrm{mg}, 0.14 \mathrm{mmol})$ was placed in $48 \%$ aqueous $\operatorname{HBr}(0.5 \mathrm{~mL})$ and heated in an oil bath held at $90^{\circ} \mathrm{C}$ for $3 \mathrm{~h}$. The yellow solution was cooled and added to THF $(10 \mathrm{~mL})$ and the mixture placed in the freezer overnight. The yellow solid was collected by filtration, washed with THF and dried to yield acridizinium bromide (9a, $35 \mathrm{mg}, 97 \%$ ), mp $248-250^{\circ} \mathrm{C}$, ${ }^{1} \mathrm{H}$ NMR spectrum identical to salt from Procedure 1.

Procedure 3. Acridizinium chloride from hemiacetal chloride 4c. The hemiacetal chloride salt $4 \mathbf{c}(90 \mathrm{mg}, 0.34 \mathrm{mmol})$ was dissolved in concentrated $\mathrm{HCl}(0.5 \mathrm{~mL})$ in an Ace pressure tube. The mixture was placed in an oil bath at $90^{\circ} \mathrm{C}$ and held at $110-125^{\circ} \mathrm{C}$ for $2.5 \mathrm{~h}$. The yellow solution was cooled and addition of THF $(20 \mathrm{~mL})$ precipitated a light yellow solid. The solid was collected by filtration, washed with THF and dried to afford acridizinium chloride (9a, where $\mathrm{Br}=\mathrm{Cl})(47 \mathrm{mg}, 64 \%)$ : The salt readily crystallized from ethanol or methanol/ethyl acetate to afford yellow crystals, mp $211-214^{\circ} \mathrm{C}(\mathrm{dec}),{ }_{1 i{ }^{21}} 206-208^{\circ} \mathrm{C} .{ }^{1} \mathrm{H}$ NMR (DMSO-d 6 ) $\delta$ 10.60 (s, 1H, H-6), 9.37 (d, J = 6.5 Hz, 1H, H-4), 9.28 (s, 1H, H-11), 8.59 (d, J = 8.5 Hz, 1H), $8.50(\mathrm{~d}, \mathrm{~J}=8.5 \mathrm{~Hz}, 1 \mathrm{H}), 8.40(\mathrm{~d}, \mathrm{~J}=9.0 \mathrm{~Hz}, 1 \mathrm{H}), 8.15(\mathrm{t}, \mathrm{J}=7.0 \mathrm{~Hz}, 1 \mathrm{H}), 8.09$ (t, J = 7.0 Hz, $1 \mathrm{H}), 8.03(\mathrm{t}, \mathrm{J}=8.0 \mathrm{~Hz}, 1 \mathrm{H}), 7.98(\mathrm{t}, \mathrm{J}=7.0 \mathrm{~Hz}, 1 \mathrm{H})$.

Procedure 4. Acridizinum tetrafluoroborate (from 3a and $\mathbf{H B F}_{4}$ ). The 1-benzyl-2-formyl pyridinium bromide ( 3a) (126 mg, $0.45 \mathrm{mmol}$ ) was dissolved in 50\% aqueous $\mathrm{HBF}_{4}(0.5 \mathrm{~mL})$. The yellow solution was placed in an oil bath at $70^{\circ} \mathrm{C}$ and kept at this temperature for 16 hours. The mixture was allowed to cool upon which a pale yellow solid separated. Some THF was added and a small amount $(23 \mathrm{mg}$ ) of a pale yellow solid was collected by filtration. Additional THF was added to the filtrate and the mixture was allowed to stand for 24 hours. The crystals were collected by filtration to afford an additional $70 \mathrm{mg}$ of acridizinium tetrafluoroborate (9a, where $\left.\mathrm{Br}=\mathrm{BF}_{4}\right)($ total of $93 \mathrm{mg}, 72 \%$ yield $), \mathrm{mp} 172-175^{\circ} \mathrm{C},{ }^{1} \mathrm{H}$ NMR identical to bromide salt

9a.

Procedure 1. 9-methyl acridizinium bromide (9b) (from 3b). The 1-(4-methylbenzyl)-2formyl pyridinium bromide (3b) (2.96 g, $0.01 \mathrm{~mol}$ ) was dissolved in 48\% aqueous $\mathrm{HBr}(12 \mathrm{~mL})$ and the solution was heated in an oil bath held at $90^{\circ} \mathrm{C}$ for $2 \mathrm{~h}$. The cooled solution was slowly poured into THF $(120 \mathrm{~mL})$ and the yellow solid which formed was collected by filtration, washed with THF and air dried to yield the desired product $9 \mathrm{~b}(2.5 \mathrm{~g}, 90 \%)$; Crystallization from ethanol led to beautiful yellow prisms. mp $180-184^{\circ} \mathrm{C}$, lit $\mathrm{mp}^{5} 191-193^{\circ} \mathrm{C}$. ${ }^{1} \mathrm{H}$ NMR $\left(\mathrm{DMSO}_{\mathrm{d}}\right.$ ) $\delta 10.39$ (s, 1H, H-6), 9.24 (d, J = $\left.7.0 \mathrm{~Hz}, 1 \mathrm{H}, \mathrm{H}-4\right), 9.09$ (s, 1H, H-11), 8.53 (d, J = $8.9 \mathrm{~Hz}, 1 \mathrm{H}), 8.40$ (d, J = 8.7 Hz, 1H), 8.17 (s, 1H, H-10), 8.06-8.00 (m, 1H), 7.93-7.85 (m, 2H), $2.67\left(\mathrm{~s}, 3 \mathrm{H}, 9-\mathrm{CH}_{3}\right) .{ }^{13} \mathrm{C} \mathrm{NMR}\left(\mathrm{DMSO}_{-} \mathrm{d}_{6}+\mathrm{H}_{2} \mathrm{O}\right) \delta 147.3,138.7,137.5,135.7,134.6,134.0$, $131.6,127.9,127.2,125.3,124.7,123.6,123.0,23.0$. 
Procedure 2. From the crude orange solid from treatment of 9-methyl acridizinium bromide (9b) with hydroxide. The crude orange solid (20 mg, $0.09 \mathrm{mmol}$ ) was added to $48 \%$ aqueous $\mathrm{HBr}$ and the solution allowed to stand at room temperature for $48 \mathrm{~h}$. THF (20 mL) was added and the mixture was placed in the freezer. On standing overnight, a yellow-orange oil separated. The THF was decanted and the structure of this oil (10 mg) was identified as 9methylacridizinim bromide by ${ }^{1} \mathrm{H}$ NMR. The THF on standing in the hood deposited beautiful yellow needles of the salt $9 \mathrm{~b}(10 \mathrm{mg}, 73 \%)$.

Procedure 3. (From imine 11h). Imine 11h (200 mg, $0.73 \mathrm{mmol}$ ) was dissolved in 48\% aqueous $\mathrm{HBr}(1 \mathrm{~mL})$ and the solution was placed in an oil bath held at $90^{\circ} \mathrm{C}$ for $3 \mathrm{~h}$. The mixture was allowed to stand overnight, then partially concentrated under a slow stream of nitrogen and THF ( $5 \mathrm{~mL}$ ) was added. The resulting solid was collected by filtration to yield predominantly 9methyl acridizinium bromide (9b) partially contaminated with the hydrobromide salt of 1propylamine (about $20 \%$ ) based on the ${ }^{1} \mathrm{H}$ NMR spectral data integral comparisons.

Procedure 4. (from oxime 11e). The oxime 11e (0.103 g, $0.46 \mathrm{mmol})$ in $48 \%$ aqueous $\mathrm{HBr}($ $0.75 \mathrm{~mL}$ ) was heated in an oil bath held at $80-90^{\circ} \mathrm{C}$ for $2 \mathrm{~h}$. The cooled solution was poured into THF $(15 \mathrm{~mL})$ and the precipitated yellow solid collected by filtration to afford $9 \mathrm{~b}(0.11 \mathrm{~g}, 80 \%)$. 7,10-Dimethoxyacridizinium bromide (9c). The dimethoxy salt 3c (39 $\mathrm{mg}, 0.11 \mathrm{mmol}$ ) was treated with $48 \%$ aqueous $\mathrm{HBr}$ and the mixture was heated in an oil bath held at $50^{\circ} \mathrm{C}$ for $0.5 \mathrm{~h}$. The cooled orange solution was poured in THF $(10 \mathrm{~mL})$ on which an orange solid separated. After allowing the mixture to stand for $1 \mathrm{~h}$, the solid 9c was collected by filtration (35 $\mathrm{mg}$, quantitative). The product readily crystallized from ethyl acetate-methanol or ethanol, $\mathrm{mp}$ $>235^{\circ} \mathrm{C}(\mathrm{dec}) .{ }^{1} \mathrm{H}$ NMR $\left(\mathrm{DMSO}_{6}\right) \delta 10.41(\mathrm{~s}, 1 \mathrm{H}), 9.49(\mathrm{~d}, \mathrm{~J}=6.5 \mathrm{~Hz}, 1 \mathrm{H}), 9.26(\mathrm{~s}, 1 \mathrm{H}), 8.69$ $(\mathrm{d}, \mathrm{J}=8.5 \mathrm{~Hz}, 1 \mathrm{H}), 8.09(\mathrm{~m}, 1 \mathrm{H}), 7.96(\mathrm{t}, \mathrm{J}=7.0 \mathrm{~Hz}, 1 \mathrm{H}), 7.44(\mathrm{~d}, \mathrm{~J}=8.5 \mathrm{~Hz}, 1 \mathrm{H}), 7.28(\mathrm{~d}, \mathrm{~J}=$ $8.5 \mathrm{~Hz}, 1 \mathrm{H}), 4.12(\mathrm{~s}, 3 \mathrm{H}), 4.09(\mathrm{~s}, 3 \mathrm{H})$.

${ }^{13} \mathrm{C}$ NMR (DMSO-d $\left.{ }_{6}\right) \delta 148.4,147.0,137.4,135.3,134.6,131.5,128.2,127.0,122.4,119.4$, 119.2, 111.5, 107.6, 56.5, 56.4. Anal. Calcd. for $\mathrm{C}_{15} \mathrm{H}_{14} \mathrm{BrNO}_{2}$ : C, 56.27, H, 4,41, N, 4.37. Found: 56.06, H, 4.23, N, 4.19 .

6-Methylacridizinium bromide (9d). The pyridinium salt $6(0.58 \mathrm{~g}, 1.73 \mathrm{mmol})$ was treated with $48 \%$ aqueous $\mathrm{HBr}(1.2 \mathrm{~mL})$ and the mixture placed in an oil bath at $70^{\circ} \mathrm{C}$. The mixture was held at $90^{\circ} \mathrm{C}$ temperature for $4 \mathrm{~h}$, cooled and allowed to stand overnight. The orange solution was then quenched into THF $(40 \mathrm{~mL})$ on which a bright yellow solid formed. The mixture was allowed to stand overnight and the resultant lemon-yellow solid was collected by filtration and air dried to yield the bromide salt 9d $(0.33 \mathrm{~g}, 70 \%)$ which could be recystallized from ethanol to afford yellow prisms or from ethanol as yellow needles; mp $227-229^{\circ} \mathrm{C}$, lit $\mathrm{mp}^{20} 230$ $231.5^{\circ} \mathrm{C} \quad{ }^{1} \mathrm{H}$ NMR (DMSO-d 6$) 9.35$ (d, J = 7.5 Hz, 1H, H-4), 9.23 (s, 1H, H-11), 8.84 (d, J = 8.9 $\mathrm{Hz}, 1 \mathrm{H}), 8.60(\mathrm{~d}, \mathrm{~J}=8.6 \mathrm{~Hz}, 1 \mathrm{H}), 8.41(\mathrm{~d}, \mathrm{~J}=8.5 \mathrm{~Hz}, 1 \mathrm{H}), 8.15(\mathrm{t}, \mathrm{J}=6.9 \mathrm{~Hz}, 1 \mathrm{H}), 8.09(\mathrm{t}, \mathrm{J}=$ $6.9 \mathrm{HZ}, 1 \mathrm{H}), 8.06(\mathrm{t}, \mathrm{J}=7.6 \mathrm{~Hz}, 1 \mathrm{H}), 7.99(\mathrm{t}, \mathrm{J}=6.7 \mathrm{~Hz}, 1 \mathrm{H}), 3.50(\mathrm{~s}, 3 \mathrm{H}) .{ }^{13} \mathrm{C}$ NMR (DMSO$\left.\mathrm{d}_{6}\right) \delta 148.4,137.8,134.9,134.3,131.4,130.7,130.2,128.3,128.2,127.4,125.8,124.6,123.1$, 17.0. 
11-Methyl acridizinium bromide (9e). Pyridizinium salt 8a (136 mg) was dissolved in 48\% aqueous $\mathrm{HBr}(0.5 \mathrm{~mL})$ and placed in an oil bath heated at $90-100^{\circ} \mathrm{C}$ for $3 \mathrm{~h}$. The cooled solution was added to THF $(10 \mathrm{~mL})$ and the mixture was placed in the freezer. Yellow needles separated which were collected by filtration (13 mg, not pure by $\left.{ }^{1} \mathrm{H} \mathrm{NMR}\right)$. Crystallization from ethanol led to a few yellow crystals, mp $195-197^{\circ} \mathrm{C}$, lit mp ${ }^{11} 199-201{ }^{\circ} \mathrm{C} .{ }^{1} \mathrm{H}$ NMR (DMSO-d $610.40(\mathrm{~s}$, 1H, H-6), 9.30 (d, J = 7.0 Hz, 1H, H-4), 8.81 (d, J = 9.0 Hz, 1H), 8.65 (d, J = 9.0 Hz, 1H), 8.48 $(\mathrm{d}, \mathrm{J}=8.5 \mathrm{~Hz}, 1 \mathrm{H}), 8.18(\mathrm{~m}, 1 \mathrm{H}), 8.10(\mathrm{~m}, 1 \mathrm{H}), 9.02(\mathrm{~m}, 1 \mathrm{H}), 7.98(\mathrm{~m}, 1 \mathrm{H}), 3.20(\mathrm{~s}, 3 \mathrm{H})$.

9,11-Dimethylacridizinium bromide (9f). The 2-acetyl-1-(4-methylbenzyl)pyridinium bromide (8b) (270 mg, $0.88 \mathrm{mmol})$ was dissolved in $48 \%$ aqueous $\mathrm{HBr}(1 \mathrm{~mL})$ and the solution was heated in an oil bath the temperature of which was held at $120^{\circ}-130^{\circ} \mathrm{C}$ for $1.5 \mathrm{~h}$ during which period an oil separated. The mixture was cooled and added to THF (75 mL) which afforded a yellow solid. The mixture was allowed to stand overnight at room temperature and the solid was collected by filtration to afford the salt $(9 \mathrm{f}, 0.14 \mathrm{~g}, 56 \%)$. The salt readily crystallized from ethanol, mp $>370^{\circ} \mathrm{C}$. ${ }^{1} \mathrm{H}$ NMR $\left(\mathrm{DMSO}_{6}\right) \delta 10.35$ (s, 1H, H-6), 9.26 (d, J = 7.0 Hz, 1H, H-4), $8.72(\mathrm{~d}, \mathrm{~J}=9.0 \mathrm{~Hz}, 1 \mathrm{H}), 8.38(\mathrm{~s}, 1 \mathrm{H}, \mathrm{H}-10), 8.35$ (d, J = 8.7 Hz, 1H), 8.04 (t, J = 6.8 Hz, 1H), $7.92(\mathrm{t}, \mathrm{J}=6.8 \mathrm{~Hz}, 1 \mathrm{H}), 7.86(\mathrm{~d}, \mathrm{~J}=8.6 \mathrm{~Hz}, 1 \mathrm{H}), 3.12(\mathrm{~s}, 3 \mathrm{H}), 2.70(\mathrm{~s}, 3 \mathrm{H}) .{ }^{13} \mathrm{C} \mathrm{NMR}\left(\mathrm{DMSOd}_{6}\right.$ $\left.+\mathrm{H}_{2} \mathrm{O}\right) \delta 145.8,138.2$, 136.0, 134.7, 134.3, 133.2, 130.5, 130.2, 128.5, 124.0, 123.9, 122.8, 121.4, 22.4, 13.6. Anal. Calcd. for $\mathrm{C}_{15} \mathrm{H}_{14} \mathrm{BrN}$ : C, 62.52, H, 4.90, N, 4.86. Found: C, 62.25, H, 4.64, N, 4.76.

Procedure 1. 2-(2-formylbenzyl)pyridine (11a ). A solution of acridizinium bromide (9a) (29 $\mathrm{mg}, 0.09 \mathrm{mmol})$ in water $(0.6 \mathrm{~mL})$ was treated rapidly with $10 \%$ aqueous $\mathrm{NaOH}(0.2 \mathrm{~mL})$. An orange solid immediately formed and the mixture was stirred for $1 \mathrm{~h}$ during which period the color of the solid changed to a lighter orange color. The solid was collected by filtration, washed with water and dried to yield $15 \mathrm{mg}(85 \%)$ of product as a light pink material. The ${ }^{1} \mathrm{H}$ NMR data were obtained in $\mathrm{CDCl}_{3}$ and $\mathrm{C}_{6} \mathrm{H}_{6}$. Both indicated the presence of the ring-opened aldehyde 11a ( absorptions at $\delta 10.3$ and 4.6 for $\mathrm{CDCl}_{3}$ and 10.18 and 4.40 for $\mathrm{C}_{6} \mathrm{D}_{6}$ along with other peaks). ${ }^{1} \mathrm{H} \mathrm{NMR}\left(\mathrm{CDCl}_{3}\right) \delta 10.29(\mathrm{~s}, 1 \mathrm{H}), 8.51(\mathrm{~d}, \mathrm{~J}=4.8 \mathrm{~Hz}, 1 \mathrm{H}), 7.85(\mathrm{~d}, \mathrm{~J}=7.7 \mathrm{~Hz}, 1 \mathrm{H}), 7.54$ $(\mathrm{m}, 2 \mathrm{H}), 7.43(\mathrm{t}, \mathrm{J}=7.1 \mathrm{~Hz}, 1 \mathrm{H}), 7.38(\mathrm{~d}, \mathrm{~J}=4.8 \mathrm{~Hz}, 1 \mathrm{H}), 7.22(\mathrm{~m}, 1 \mathrm{H}), 4.60(\mathrm{~s}, 2 \mathrm{H}) .{ }^{1} \mathrm{H}$ NMR $\left(\mathrm{C}_{6} \mathrm{D}_{6}\right) \delta 10.18(\mathrm{~s}, 1 \mathrm{H}), 8.33(\mathrm{~J}=4.5 \mathrm{~Hz}, 1 \mathrm{H}), 7.60(\mathrm{~J}=7.5 \mathrm{~Hz}, 1 \mathrm{H}), 6.95(\mathrm{~m}, 2 \mathrm{H}), 6.93(\mathrm{~m}, 2 \mathrm{H})$, $6.81(\mathrm{~d}, \mathrm{~J}=7.8 \mathrm{~Hz}, 1 \mathrm{H}) 6.50(\mathrm{~m}, 1 \mathrm{H}), 4.40(\mathrm{~s}, 2 \mathrm{H})$.

Procedure 2. A solution of acridizinium bromide $(\mathbf{9 a})(10 \mathrm{mg})$ in water $(0.3 \mathrm{~mL})$ was treated with $10 \%$ aqueous $\mathrm{NaOH}$ ( 8 drops, $\mathrm{pH}=14$ ) to yield an orange precipitate. The mixture was stirred for 20 minutes and then $\mathrm{CDCl}_{3}(0.6 \mathrm{~mL})$ was added. The $\mathrm{CDCl}_{3}$ layer was separated, dried over $\mathrm{Na}_{2} \mathrm{SO}_{4}$ and the ${ }^{1} \mathrm{H}$ NMR recorded. The presence of mainly the ring-opened aldehyde 11a was indicated. Similar results were found using $0.1 \%(\mathrm{pH}=12.5)$ or $2 \%(\mathrm{pH}=14)$ aqueous $\mathrm{NaOH}$.

Procedure 1. 2-(2-Formyl-5-methylbenzyl)pyridine (11b). A solution of 9-methyl acridizinium bromide (9b) $(66 \mathrm{mg}, 0.24 \mathrm{mmol})$ in water $(1.3 \mathrm{~mL})$ was treated with $10 \%$ aqueous $\mathrm{NaOH}(0.2 \mathrm{~mL})$. An immediate orange precipitate formed and the mixture was allowed to stir for $1 \mathrm{~h}$. The solid was collected by filtration, washed with water and the ${ }^{1} \mathrm{H}$ NMR rapidly 
recorded in $\mathrm{CDCl}_{3}$ and also $\mathrm{C}_{6} \mathrm{D}_{6}$. Both indicated the presence of the ring-opened product but numerous other peaks were also observed. However, if the NMR was recorded again after the NMR solutions stood for $18 \mathrm{~h}$, both solutions now indicated the presence of nearly pure ringopened aldehyde 11b (only trace contamination). ${ }^{1} \mathrm{H}$ NMR $\left(\mathrm{CDCl}_{3}\right) \delta 10.21(\mathrm{~s}, 1 \mathrm{H}), 8.51(\mathrm{~d}, \mathrm{~J}=$ $4.3 \mathrm{~Hz}, 1 \mathrm{H}), 7.75(\mathrm{~d}, \mathrm{~J}=7.8 \mathrm{~Hz}, 1 \mathrm{H}), 7.55(\mathrm{dt}, \mathrm{J}=7.7,1.7 \mathrm{~Hz}, 1 \mathrm{H}), 7.21(\mathrm{~d}, \mathrm{~J}=7.6 \mathrm{~Hz}, 1 \mathrm{H})$, $7.16(\mathrm{~s}, 1 \mathrm{H}), 7.08(\mathrm{~m}, 2 \mathrm{H}), 4.56(\mathrm{~s}, 2 \mathrm{H}), 2.38(\mathrm{~s}, 3 \mathrm{H}) .{ }^{1} \mathrm{H}$ NMR $\left(\mathrm{C}_{6} \mathrm{D}_{6}\right) \delta 10.18(\mathrm{~s}, 1 \mathrm{H}), 8.36(\mathrm{~d}, \mathrm{~J}$ $=4.4 \mathrm{~Hz}, 1 \mathrm{H}), 7.55(\mathrm{~d}, \mathrm{~J}=7.8 \mathrm{~Hz}, 1 \mathrm{H}), 6.99(\mathrm{~s}, 1 \mathrm{H}), 6.95(\mathrm{dt}, \mathrm{J}=7.7,1.8 \mathrm{~Hz}, 1 \mathrm{H}), 6.90(\mathrm{~d}, \mathrm{~J}=$ $7.8 \mathrm{~Hz}, 1 \mathrm{H}), 6.75$ (d, J = 7.6 Hz, 1H), $6.50(\mathrm{~m}, 1 \mathrm{H}), 4.46(\mathrm{~s}, 2 \mathrm{H}), 1.92(\mathrm{~s}, 3 \mathrm{H})$.

Procedure 2. A solution of 9-methylacridizinium bromide $(9 \mathrm{~b})(8 \mathrm{mg})$ in water $(0.3 \mathrm{ml})$ was treated with a saturated aqueous $\mathrm{Na}_{2} \mathrm{CO}_{3}$ solution (6 drops, $\mathrm{pH}=12.5$ ) to afford an orange precipitate which was extracted into $\mathrm{CDCl}_{3}$. After drying over $\mathrm{Na}_{2} \mathrm{SO}_{4},{ }^{1} \mathrm{H} \mathrm{NMR}$ analysis indicated predominantly the ring-opened aldehyde $\mathbf{1 1 b}$.

Procedure 3. A solution of 9-methyl acridizinium bromide (9b) (9 mg) in water $(0.3 \mathrm{~mL})$ was treated dropwise with aqueous $0.1 \% \mathrm{NaOH}$ to afford an orange precipitate. The mixture was stirred for 15 minutes and $\mathrm{CDCl}_{3}(0.6 \mathrm{~mL})$ was added. The $\mathrm{CDCl}_{3}$ layer was separated, dried over $\mathrm{Na}_{2} \mathrm{SO}_{4}$ and analyzed by NMR. The predominant product was the ring opened-aldehyde 11b. ${ }^{1} \mathrm{H}$ NMR $\left(\mathrm{CDCl}_{3}\right) \delta 10.22(\mathrm{~s}, 1 \mathrm{H}), 8.51(\mathrm{~d}, \mathrm{~J}=4.2 \mathrm{~Hz}, 1 \mathrm{H}), 7.75(\mathrm{~d}, \mathrm{~J}=7.8 \mathrm{~Hz}, 1 \mathrm{H}), 7.54$ $(\mathrm{dt}, \mathrm{J}=7.8,1.6 \mathrm{~Hz}, 1 \mathrm{H}), 7.20(\mathrm{~d}, \mathrm{~J}=7.4 \mathrm{~Hz}, 1 \mathrm{H}), 7.08(\mathrm{~m}, 2 \mathrm{H}), 4.56(\mathrm{~s}, 2 \mathrm{H}), 2.38$ (s, 3H).

Procedure 1. 2-(2-Acetylbenzyl)pyridine (11c). Treatment of 6-methylacridizinium bromide (9d) $(8.5 \mathrm{mg})$ in water $(0.2 \mathrm{~mL})$ with $2 \%$ aqueous $\mathrm{NaOH}(10$ drops, $\mathrm{pH}=14)$ and stirring led to an instant color change with the formation of some tan suspended material. After 20 minutes, $\mathrm{CDCl}_{3}(0.5 \mathrm{ml})$ was added and the organic lower orange layer was separated, dried over $\mathrm{Na}_{2} \mathrm{SO}_{4}$ and analysis by ${ }^{1} \mathrm{H}$ NMR indicated the presence of nearly pure ring-opened product 11c. Evaporation of the $\mathrm{CDCl}_{3}$ led to a black residue. ${ }^{1} \mathrm{H} \mathrm{NMR}\left(\mathrm{CDCl}_{3}\right) \delta 8.53(\mathrm{~d}, \mathrm{~J}=4.3 \mathrm{~Hz}, 1 \mathrm{H})$, $7.72(\mathrm{~d}, \mathrm{~J}=8.6 \mathrm{~Hz}, 1 \mathrm{H}), 7.57(\mathrm{dt}, \mathrm{J}=7.7,1.8 \mathrm{~Hz}, 1 \mathrm{H}), 7.45(\mathrm{~m}, 1 \mathrm{H}), 7.34(\mathrm{~m}, 2 \mathrm{H}), 7.16(\mathrm{~d}, \mathrm{~J}=$ $7.8 \mathrm{~Hz}, 1 \mathrm{H}), 7.10(\mathrm{~m}, 1 \mathrm{H}), 4.48(\mathrm{~s}, 2 \mathrm{H}), 2.57(\mathrm{~s}, 3 \mathrm{H})$.

Procedure 2. Treatment of 6-methyl acridizinium bromide (9d) (11 $\mathrm{mg}, 0.04 \mathrm{mmol})$ in water $(0.3 \mathrm{~mL})$ with $10 \%$ aqueous $\mathrm{NaOH}$ (3 drops) led to a dark coloration. After stirring for 1 minute, $\mathrm{C}_{6} \mathrm{D}_{6}$ was added, the layer was separated and dried over $\mathrm{Na}_{2} \mathrm{SO}_{4}$. The ${ }^{1} \mathrm{H}$ NMR of the $\mathrm{C}_{6} \mathrm{D}_{6}$ solution indicated the major component as the ring-opened aldehyde 11c. ${ }^{1} \mathrm{H} N M R\left(\mathrm{C}_{6} \mathrm{D}_{6}\right) \delta 8.37$ $(\mathrm{d}, \mathrm{J}=4.7 \mathrm{~Hz}, 1 \mathrm{H}), 7.28(\mathrm{~d}, \mathrm{~J}=7.7 \mathrm{~Hz}, 1 \mathrm{H}), 7.05(\mathrm{~J}=7.5 \mathrm{~Hz}, 1 \mathrm{H}), 7.02(\mathrm{~m}, 3 \mathrm{H}), 6.90(\mathrm{t}, \mathrm{J}=7.6$ $\mathrm{Hz}, 1 \mathrm{H}), 6.53(\mathrm{~m}, 1 \mathrm{H}), 4.62(\mathrm{~s}, 2 \mathrm{H}), 2.12(\mathrm{~s}, 3 \mathrm{H})$.

2-Pyridin-2-ylmethyl-benzaldehyde oxime (11d ). Acrizidinium bromide (9a) (250 mg, 0.96 mmol) was dissolved in $\mathrm{H}_{2} \mathrm{O}(3.7 \mathrm{~mL})$ A solution prepared by dissolving $\mathrm{NH}_{2} \mathrm{OH} \cdot \mathrm{HCl}(90 \mathrm{mg}$, $1.3 \mathrm{mmol})$ in $\mathrm{H}_{2} \mathrm{O}(0.6 \mathrm{~mL})$ and neutralized with $\mathrm{NaHCO}_{3}$ (excess) was added rapidly. The suspension was stirred for 45 minutes and then placed in the refrigerator for 30 minutes. The precipitate was collected by filtration to afford $11 \mathrm{~d}(137 \mathrm{mg}, 68 \%)$ as a pale yellow powder; $\mathrm{mp}$ $167-169^{\circ} \mathrm{C}$, lit. ${ }^{18} 156-157^{\circ} \mathrm{C} .{ }^{1} \mathrm{H} \mathrm{NMR}\left(\mathrm{CDCl}_{3}\right) \delta 9.33$ (bs, $\left.1 \mathrm{H}, \mathrm{NOH}\right), 8.51(\mathrm{~d}, \mathrm{~J}=4.8 \mathrm{~Hz}, 1 \mathrm{H})$, $8.41(\mathrm{~s}, 1 \mathrm{H}, \mathrm{CH}=\mathrm{N}), 7.67(\mathrm{~d}, \mathrm{~J}=7.6 \mathrm{~Hz}, 1 \mathrm{H}), 7.56-7.52(\mathrm{~m}, 1 \mathrm{H}), 7.33(\mathrm{t}, \mathrm{J}=7.0 \mathrm{~Hz}, 1 \mathrm{H}), 7.29$ 
$(\mathrm{m}, 2 \mathrm{H}), 7.11-7.08(\mathrm{~m}, 1 \mathrm{H}), 6.95(\mathrm{~d}, \mathrm{~J}=7.9 \mathrm{~Hz}, 1 \mathrm{H}), 4.39\left(\mathrm{~s}, 2 \mathrm{H}, \mathrm{CH}_{2}\right) .{ }^{13} \mathrm{C} \mathrm{NMR}\left(\mathrm{CDCl}_{3}\right) \delta$ $160.4,149.0,137.5,136.8,131.3,131.2,129.7,127.9,127.1,122.9,121.3,41.9$.

4-Methyl-2-pyridin-2-ylmethyl-benzaldehyde oxime (11e). The 9-methyl acridizinium bromide (9b) $0.25 \mathrm{~g}, 0.9 \mathrm{mmol}$ ) was treated with a solution of hydroxylamine hydrochloride ( $0.14 \mathrm{~g}, 2 \mathrm{mmol})$ and saturated $\mathrm{NaHCO}_{3}(1 \mathrm{~mL})$. On stirring the mixture for $0.5 \mathrm{~h}$, the precipitated solid was collected by filtration, washed with water and dried to yield the oxime 11e $(0.18 \mathrm{~g}, 90 \%), \mathrm{mp} 110-112^{\circ} \mathrm{C}$. The material readily crystallized from aqueous ethanol to afford white needles, mp $112-113^{\circ} \mathrm{C} .{ }^{1} \mathrm{H}$ NMR $\left(\mathrm{CDCl}_{3}\right) \delta 8.52(\mathrm{~d}, \mathrm{~J}=4.7 \mathrm{~Hz}, 1 \mathrm{H}), 8.38(\mathrm{~s}, 1 \mathrm{H}), 7.91$ (br s, $0.6 \mathrm{H}), 7.58(\mathrm{~d}, \mathrm{~J}=7.8 \mathrm{~Hz}, 1 \mathrm{H}), 7.52(\mathrm{dt}, \mathrm{J}=7.7,1.8 \mathrm{~Hz}, 1 \mathrm{H}), 7.07(\mathrm{~m}, 3 \mathrm{H}), 6.95(\mathrm{~d}, \mathrm{~J}=$ $7.8 \mathrm{~Hz}, 1 \mathrm{H}), 4.31(\mathrm{~s}, 2 \mathrm{H}), 2.33(\mathrm{~s}, 3 \mathrm{H}) .{ }^{1} \mathrm{H} \mathrm{NMR}\left(\mathrm{CDCl}_{3}+\mathrm{D}_{2} \mathrm{O}\right) \delta 8.53(\mathrm{~d}, \mathrm{~J}=4.8 \mathrm{HZ}, 1 \mathrm{H}), 8.37$ (s, 1H), $7.58(\mathrm{~d}, 7.8 \mathrm{~Hz}, 1 \mathrm{H}), 7.53(\mathrm{dt}, \mathrm{J}=7.7,1.8 \mathrm{~Hz}, 1 \mathrm{H}), 7.09(\mathrm{~m}, 3 \mathrm{H}), 6.95$ (d, J = 7.8 Hz, $1 \mathrm{H}), 4.32(\mathrm{~s}, 2 \mathrm{H}), 2.33$ (s, 3H). Anal. Calcd. for $\mathrm{C}_{14} \mathrm{H}_{14} \mathrm{~N}_{2} \mathrm{O}$ : C, 74.31, H, 6.24, N, 12.38. Found: C, 74.02, H, 6.12, N, 12.19 .

2-Pyridin-2-ylmethyl-benzaldehyde $\boldsymbol{O}$-phenyl oxime (11f ). Acridizinium bromide (9a) (200 $\mathrm{mg}, 0.77 \mathrm{mmol})$ was dissolved in an aqueous solution of $\mathrm{NaHCO}_{3}(162 \mathrm{mg}, 1.93 \mathrm{mmol}$ in 2.5 $\mathrm{mL}$ of water). To the stirring solution was added portion wise $O$-benzylhydroxylamine hydrochloride $(123 \mathrm{mg}, 0.77 \mathrm{mmol})$. A red oil separated and $\mathrm{CH}_{2} \mathrm{Cl}_{2}(2 \mathrm{~mL})$ was added. The mixture was stirred for 30 minutes, the aqueous layer was discarded, the organic phase was washed with brine, dried over $\mathrm{Na}_{2} \mathrm{SO}_{4}$ and the solvent removed at diminished pressure. The crude red oil was purified via column chromatography (neutral alumina, $\mathrm{CH}_{2} \mathrm{Cl}_{2}$ ) to afford $\mathbf{1 1 f}$ (144 mg, 62\%) as an almost colorless oil. ${ }^{1} \mathrm{H}$ NMR (DMSO-d 6$): \delta 8.62(\mathrm{~s}, 1 \mathrm{H}), 8.4(\mathrm{~d}, \mathrm{~J}=5.1$ $\mathrm{Hz}, 1 \mathrm{H}), 7.68-7.64(\mathrm{~m}, 2 \mathrm{H}), 7.36-7.26(\mathrm{~m}, 8 \mathrm{H}), 7.20-7.14(\mathrm{~m}, 2 \mathrm{H}), 5.13(\mathrm{~s}, 2 \mathrm{H}), 4.27(\mathrm{~s}, 2 \mathrm{H}) .{ }^{13} \mathrm{C}$ NMR (DMSO-d $\left.)_{6}\right): \delta 160.0,149.0,148.1,138.4,137.6,136.6,131.1,130.2,129.8,128.2,128.0$, 127.6, 126.7, 126.6, 122.8, 121.3, 75.2, 40.7. Anal. Calcd. for $\mathrm{C}_{20} \mathrm{H}_{18} \mathrm{~N}_{2} \mathrm{O}: \mathrm{C}, 79.44, \mathrm{H}, 6.00, \mathrm{~N}$, 9.26. Found: C, 79.19, H, 5.98, N, 9.27.

1-(2-Pyridin-2-ylmethylphenyl)ethanone oxime (11g). The 6-methyl acridizinium bromide (9d) $(100 \mathrm{mg}, 0.36 \mathrm{mmol})$ in water $(2 \mathrm{~mL})$ was treated with a solution of hydroxylamine [prepared from hydroxylamine hydrochloride $(50 \mathrm{mg}, 0.72 \mathrm{~mol})$ and saturated $\mathrm{NaHCO}_{3}(2 \mathrm{~mL})$ ]. After 20 minutes a solid precipitated and the mixture was allowed to stir for $0.5 \mathrm{~h}$. The crystalline solid was collected by filtration and dried to yield the oxime $\mathbf{1 1 g}(55 \mathrm{mg}, 68 \%)$. The sample was recrystallized from aqueous ethanol to afford beautiful white needles, mp 152$153^{\circ} \mathrm{C}$. ${ }^{1} \mathrm{H}$ NMR (DMSO-d 6 ) $\delta 10.97$ (s) $10.40(\mathrm{~s}),, 8.44(\mathrm{~d}, \mathrm{~J}=4.5 \mathrm{~Hz}, 1 \mathrm{H}), 7.65$ (t, J = 7.6 Hz, 1H), $7.22(\mathrm{~m} \mathrm{4H}), 7.18(\mathrm{~m}, 1 \mathrm{H}), 7.10$ (d, J = 7.8 Hz, 1H), 4.18 (s) 4.00 (s), 1.99 (s), 1.91(s), presence of $\mathrm{E}$ and $\mathrm{Z}$ isomers shown by peaks at $\delta 10.97$ and 10.40 (ratio 9:1); 4.18 and 4.00 (ratio 9:1) and 1.99 and 1.91 (9:1). ${ }^{1} \mathrm{H}$ NMR (DMSO- $\mathrm{d}_{6}+\mathrm{D}_{2} \mathrm{O}$ ) disappearance of the $\delta 10.97$ and 10.40 peaks (NOH). Anal. Calcd for $\mathrm{C}_{14} \mathrm{H}_{14} \mathrm{~N}_{2} \mathrm{O}$ : C, 74.31, H. 6.24, N, 12.28. Found: 74.02, $\mathrm{H}, 6.25, \mathrm{~N}, 12.18$.

(4-Methyl-2-pyridin-2-ylmethyl-benzylidene)-propylamine (11h). Salt 9b (200 mg, 0.73 mmol, yellow solid) was treated with 1 -aminopropane $(0.5 \mathrm{~mL})$ upon which an orange solution immediately formed. Dichloromethane $(5 \mathrm{~mL})$ was added and the solution was washed with 
water $(3 \times 4 \mathrm{~mL})$. The dichloromethane extract was dried over $\mathrm{Na}_{2} \mathrm{SO}_{4}$ and the solvent was removed by rotary evaporation to afford $11 \mathrm{~h}$ as an orange oil $(0.18 \mathrm{~g}$, quantitative). Attempts to effect further purification were unsuccessful. ${ }^{1} \mathrm{H} \mathrm{NMR}\left(\mathrm{CDCl}_{3}\right) \delta 8.53(\mathrm{~d}, \mathrm{~J}=5.0 \mathrm{~Hz}, 1 \mathrm{H}), 8.51$ $(\mathrm{s}, 1 \mathrm{H}), 7.80(\mathrm{~d}, \mathrm{~J}=7.8 \mathrm{~Hz}, 1 \mathrm{H}), 7.53-7.49(\mathrm{~m}, 1 \mathrm{H}), 7.11(\mathrm{~d}, \mathrm{~J}=7.8 \mathrm{~Hz}, 1 \mathrm{H}), 7.09-7.06(\mathrm{~m}, 2 \mathrm{H})$, $6.96(\mathrm{~d}, \mathrm{~J}=8.0 \mathrm{~Hz}, 1 \mathrm{H}), 4.40\left(\mathrm{~s}, 2 \mathrm{H}, \mathrm{CH}_{2}\right), 3.47\left(\mathrm{~m}, 2 \mathrm{H}, \mathrm{CH}_{2}\right), 2.35$ (s, 3H, $\left.\mathrm{CH}_{3}\right), 1.61$ (q, J = 7.1 $\left.\mathrm{Hz}, 2 \mathrm{H}, \mathrm{CH}_{2}\right), 0.83\left(\mathrm{t}, \mathrm{J}=7.4 \mathrm{~Hz}, 3 \mathrm{H}, \mathrm{CH}_{3}\right) .{ }^{13} \mathrm{C} \mathrm{NMR}\left(\mathrm{CDCl}_{3}\right): \delta 160.9,159.3,149.2,140.3$, 138.2, 136.4, 132.1, 131.7, 128.1, 127.9, 122.9, 121.0, 63.7, 41.53, 23.9, 21.3, 11.6.

$\mathbf{N , N - D i m e t h y l - N ' - ( 2 - p y r i d i n - 2 - y l m e t h y l - b e n z y l i d e n e ) - e t h a n e - 1 , 2 - d i a m i n e ~ ( 1 1 i ) . ~ S a l t ~ 9 a ~ ( 2 5 0 ~}$ $\mathrm{mg}, 0.96 \mathrm{mmol})$ was suspended in $N, N$-dimethylethylenediamine $(1 \mathrm{~mL})$ and the initial suspension slowly became a clear solution. Chloroform was added and the solution was washed 3 times with water. The solvent was dried over $\mathrm{MgSO}_{4}$ and removed at reduced pressure to yield $11 \mathrm{i}$ as a red oil $(224 \mathrm{mg}, 87 \%) .{ }^{1} \mathrm{H} \mathrm{NMR}\left(\mathrm{CDCl}_{3}\right) \delta 8.59(\mathrm{~s}, 1 \mathrm{H}), 8.51(\mathrm{~d}, \mathrm{~J}=5.02 \mathrm{~Hz}, 1 \mathrm{H}), 7.88$ $(\mathrm{d}, \mathrm{J}=7.6 \mathrm{~Hz}, 1 \mathrm{H}), 7.50-47(\mathrm{~m}, 1 \mathrm{H}), 7.35-7.31(\mathrm{~m}, 1 \mathrm{H}), 7.29-7.22(\mathrm{~m}, 2 \mathrm{H}), 7.06-7.04(\mathrm{~m}, 1 \mathrm{H})$, $7.94(\mathrm{~d}, \mathrm{~J}=7.8 \mathrm{~Hz}), 4.41\left(\mathrm{~s}, 2 \mathrm{H}, \mathrm{CH}_{2}\right), 3.64$ (t, J = 7.3 Hz, 2H, $\left.\mathrm{CH}_{2} \mathrm{~N}=\right), 2.51$ (t, J = 7.0 Hz, 2H, $\left.\mathrm{CH}_{2} \mathrm{~N}\right), 2.23\left(\mathrm{~s}, 6 \mathrm{H}, 2 \mathrm{CH}_{3}\right) .{ }^{13} \mathrm{C} \mathrm{NMR}\left(\mathrm{CDCl}_{3}\right) \delta 160.7,160.4,149.2,138.4,136.4,134.6,131.0$, $130.3,128.1,127.0,122.9,121.1,60.0,45.7,45.5,41.5$.

$\boldsymbol{N}, \boldsymbol{N}$-Dimethyl- $\boldsymbol{N}$-(2-pyridin-2-ylmethyl-benzylidene)-hydrazine (11j). Acrizidinium bromide (9a) (180 mg, $0.69 \mathrm{mmol})$ was dissolved in 1,1-dimethylhydrazine (1 mL). An orange solution formed and the solutions was stirred at room temperature for $30 \mathrm{~min}$. Chloroform (3 $\mathrm{mL})$ was added and the solution was washed with water, the layers separated and the extract dried over $\mathrm{Na}_{2} \mathrm{SO}_{4}$. After removal of the drying agent by filtration, the solvent was removed at diminished pressure. The crude red oil was purified by column chromatography over neutral alumina (eluent: $\mathrm{CHCl}_{3} / \mathrm{Et}_{3} \mathrm{~N}$ 98:2) to yield $\mathbf{1 1} \mathbf{j}(158 \mathrm{mg}, 78 \%$ ) as an almost colorless oil which quickly darkened on standing in air. ${ }^{1} \mathrm{H}$ NMR $\left(\mathrm{CDCl}_{3}\right) \delta 8.52(\mathrm{dd}, \mathrm{J}=5.0,1.6 \mathrm{~Hz}, 1 \mathrm{H}), 7.84(\mathrm{~d}, \mathrm{~J}=7.6 \mathrm{~Hz}$, $1 \mathrm{H}), 7.50$ (dt, J = 7.6 Hz, J = 1.8 Hz, 1H), 7.39 (s, 1H), 7.26-7.19 (m, $3 \mathrm{H}), 7.08-7.05$ (m, 1H), $6.94(\mathrm{~d}, \mathrm{~J}=7.7 \mathrm{~Hz}, 1 \mathrm{H}), 4.33(\mathrm{~s}, 2 \mathrm{H}), 2.85(\mathrm{~s}, 6 \mathrm{H}) .{ }^{13} \mathrm{C} \mathrm{NMR}\left(\mathrm{CDCl}_{3}\right) \delta 161.2,149.0,136.4$, $125.7,135.2,131.1,131.0,127.3,127.1,125.5,123.0,121.0,42.7,42.5$.

\section{Acknowledgements}

We wish to thank Novuspharma SpA ( Bresso, Italy, now merged with CTI, Seattle, WA) for providing financial support for Sergio Cadamuro (Universita di Padova, Padova, Italy ) as a visiting graduate student at the University of Vermont and to the Dreyfus foundation for a Senior Scientist Mentor Award used to support Lauren Macnee (undergraduate, University of Michigan) during the summer of 2005. 


\section{References}

1. Ihmels, H. Science of Synthesis 2005, 15, 907.

2. Bradsher, C. K. in Comprehensive Heterocyclic Chemistry, Boulton, A. J., McKillop, A., Eds.; Pergamon Press: Oxford, UK, 1984, Vol 2, Part 2a, p 525.

3. Scriven, E. F. V. in Comprehensive Heterocyclic Chemistry, Boulton, A. J.; and A. McKillop, A, Eds., , Pergamon Press, Oxford 1984,Vol 1, Part 2a, p 165.

4. Bradsher, C. K. Accounts Chem. Res. 1969, 2, 181.

5. Bradsher, C. K.; Beavers, L. E. J. Am. Chem. Soc. 1955, 77, 4812.

6. Bradsher, C. K.; Beavers, L. E. J. Am. Chem. Soc. 1956, 78, 2459.

7. Bradsher, C. K.; Dutta, N. L. J. Am. Chem. Soc. 1960, 82, 1145.

8. Watthey, J. W. H.; Doebel, K. J.; Vernay, H. F.; Lopano, A. L. J. Org. Chem. 1973, 38, 4170.

9. Bradsher, C. K.; Jones, J. H. J. Am. Chem. Soc. 1957, 79, 6033.

10. Bradsher, C. K.; Solomons, T. W. G. J. Am. Chem. Soc. 1959, 81, 2550.

11. Bradsher, C. K.; Solomons, T. W. G.; Vaughan, F. R. J. Org. Chem. 1960, $22,757$.

12. Bradsher, C. K.; Parham, J. C. J. Org. Chem. 1963, 28, 83.

13. Bradsher, C. K.; Parham, J. C. J. Heterocyclic Chem. 1964, 1, 30.

14. Bradsher, C. K.; Parham, J. C. J. Heterocyclic Chem. 1964, 1, 121.

15. Bradsher, C. K.; Sherer, J. P.; Parham, J. H. J. Chem. Eng. Data 1965, 10, 180.

16. Ihmels, H.; Leusser, D.; Pfeiffer, M.; Stalke, D. J. Org. Chem. 1999, 64, 5715.

17. Krapcho, A. P.; Cadamuro, S. A. J. Heterocyclic Chem. 2004, 41, 29.

18. Bradsher, C. K.; Sherer, J. P. J. Org. Chem. 1967, 32, 733.

19. Bradsher, C. K.; Jones, J. H. J. Am. Chem. Soc. 1959, 81, 1938.

20. Morler, D.; Krohnke, F. Liebigs Ann. Chim. 1971, 744.

21. Turner, J. D.; Bradsher, C. K. J. Org. Chem. 1967, 32, 1169. 